\title{
Improved GPCR Ligands Based on Genetically Impossible Nanobody-Peptide Fusions
}

Ross Cheloha, Fabian A. Fischer, Andrew W. Woodham, Eileen Daley, Naomi Suminski, Thomas J. Gardella, Hidde L. Ploegh

Submitted date: 14/08/2019 - Posted date: 15/08/2019

Licence: CC BY-NC-ND 4.0

Citation information: Cheloha, Ross; Fischer, Fabian A.; W. Woodham, Andrew; Daley, Eileen; Suminski, Naomi; Gardella, Thomas J.; et al. (2019): Improved GPCR Ligands Based on Genetically Impossible Nanobody-Peptide Fusions. ChemRxiv. Preprint.

Here we describe a new method for improving signalling potency and selectivity for suboptimal GPCR ligands through conjugation with receptor-targeting nanobodies

File list (2)

Manuscript text 08062019.pdf (841.20 KiB) view on ChemRxiv • download file 
Improved GPCR ligands based on genetically impossible nanobody-peptide fusions.

Ross W. Cheloha ${ }^{1}$, Fabian A. Fischer ${ }^{1}$, Andrew W. Woodham ${ }^{1}$, Eileen Daley ${ }^{2}$, Naomi Suminski ${ }^{1}$, Thomas J. Gardella ${ }^{2, \star}$, and Hidde L. Ploegh ${ }^{1, *}$

${ }^{1}$ Boston Children's Hospital and Harvard Medical School, 1 Blackfan Circle, Boston, MA 02115

${ }^{2}$ Massachusetts General Hospital and Harvard Medical School, 1 Blackfan Circle, Boston, MA 02115

*Corresponding author gardella@helix.mgh.harvard.edu

* Corresponding author hidde.ploegh@childrens.harvard.edu 
Abstract: Antibodies conjugated to bioactive compounds such as cytotoxic drugs allow targeted delivery of therapeutics to cell types of choice, based on that antibody's specificity. We present a new type of conjugate that consists of nanobodies and peptidic ligands for $G$ protein-coupled receptors (GPCRs), fused via their $\mathrm{C}$-termini. We address activation of parathyroid hormone receptor-1 (PTHR1), the target of teriparatide used to treat osteoporosis, which has proven refractory to potent activation by small molecules. We improve the signaling activity and specificity of otherwise poorly active $\mathrm{N}$-terminal peptide fragments of PTH by conjugating them to nanobodies that recognize the extracellular portion of PTHR1. These C-to-C conjugates show biological activity vastly superior to that of the parent peptide, both in vitro and in vivo. The lead conjugate possesses selectivity for PTHR1 also superior to that of teriparatide. This platform, dubbed "conjugation of ligands and antibodies for membrane proteins (CLAMPs)", is a new approach that can generate ligands for cell surface receptors with properties superior to those provided by chemistry or nature. 
Introduction: Antibodies bind tightly and specifically to their targets, even in highly complex environments. This property of antibodies has been used to deliver bioactive compounds to sites of interest, both for diagnostic and therapeutic applications ${ }^{1}$. For example, conjugates between antibodies and cytotoxic drugs (antibody-drug conjugates or ADCs) can selectively kill cancer cells ${ }^{2}$. The success of ADCs often depends on the internalization of the conjugate through endocytosis, followed by release of the cytotoxic payload. Far fewer studies have made use of antibodies to deliver bioactive compounds with sites of action at the cell surface. The conjugation of a ligand for a surface receptor to an antibody that recognizes that same receptor should increase the effective concentration of the ligand and so increase its potency and specificity, provided appropriate spatial constraints are maintained. Ideally, this method could be used with an antibody that directly targets the receptor of interest to enable application to cells and organisms without the need for their genetic modification. The G protein-coupled receptor (GPCR) family of proteins is an attractive target to pursue this approach.

Molecules that target GPCRs represent more than $25 \%$ of all approved drugs ${ }^{3}$. Antibodies and the variable fragments of camelid heavy chain-only antibodies (VHHs or nanobodies) have found increasing use for modulating GPCR signaling ${ }^{4,5}$. GPCRs and their ligands display a considerable degree of degeneracy. Several natural ligands bind to more than a single GPCR and many GPCRs can bind more than one ligand ${ }^{6,7}$. The parathyroid hormone receptors constitute one such example: a bioactive $\mathrm{N}$-terminal fragment of parathyroid hormone $(\mathrm{PTH}$, residues 1-34), used under the name teriparatide to treat osteoporosis, potently activates both type-1 and type-2 PTH-receptors (PTHR1/PTHR2) ${ }^{8}$. PTHR1/2 are part of the B-family of GPCRs which are naturally activated by large (>25 residue) peptides ${ }^{9}$. Despite intense pharmaceutical interest, no small molecule agonists of B-family GPCRs with potencies comparable to the natural ligands have been described. To address PTHR signaling and selectivity, we prepared conjugates of fragments of PTH and VHHs. VHHs are appealing building blocks for these 
conjugates, as they are the smallest antibody fragments that retain the ability to bind antigen and can be produced in high yield using bacterial expression ${ }^{10}$. The site of antigen recognition on VHHs is near the $\mathrm{N}$-terminus ${ }^{11,12}$ and the interaction of PTHR1 and PTHR2 with their ligands requires a free $\mathrm{N}$-terminus on the latter ${ }^{8,13,14}$. Using a chemo-enzymatic approach we therefore made C-to-C-terminal fusions of PTH fragments and $\mathrm{VHHs}^{15}$. These adducts, dubbed "conjugates of ligands and antibodies for membrane proteins" or CLAMPs, target either wildtype or engineered receptor variants (Figure 1). These CLAMPs display biological activities in vitro and in vivo that are vastly superior to those of the PTH fragments from which they were derived. When weakly active PTH fragments are incorporated into these conjugates, they can be made exquisitely selective for activation of only those receptors engaged by the $\mathrm{VHH}$. This stands in marked contrast to the lack of selectivity shown by $\mathrm{PTH}(1-34)^{8}$. These findings suggest that CLAMPs should be broadly applicable for the design of ligands with unique and useful properties. 


\section{Results:}

Receptor constructs and conjugates used for targeting. $\mathrm{PTH}(1-34)$ interacts with $\mathrm{PTHR} 1$ via a two-site mechanism of interaction (Figure $1 a-b)^{8,16}$. The association between the extracellular domain of PTHR1 and residues 12-34 of PTH provides the bulk of the binding energy and specificity for this interaction. The association between the transmembrane domain of PTHR1 and residues 1-14 of PTH induces a conformational change in the receptor, which initiates intracellular signaling cascades. This mode of interaction, supported by a large amount of structure-activity relationship data, has been confirmed recently by high resolution crystallographic and cryo-electron microscopy analysis of PTHR1-ligand interactions (Figure $1 \mathrm{a})^{13,14}$.

To mimic receptor association exhibited by $\mathrm{PTH}(1-34)$, we used either wild-type PTHR1 or PTHR1 variants, modified to carry an epitope in the extracellular domain recognized by a $\mathrm{VHH}$ of choice. While there is no structural information for any VHH bound to PTHR1, we envisioned a mode of interaction between the receptor and $\mathrm{VHH}-\mathrm{PTH}$ conjugates like that depicted in Figure 1c. The portion of PTHR1 encoded by exon 2 is not resolved in structural studies (Figure 1d $)^{13,14,17}$, is not important for ligand binding ${ }^{18}$, and in past work has been targeted as a site for receptor modification ${ }^{18,19}$. We used a receptor construct in which a green fluorescent protein variant (GFP) was inserted into the portion of the receptor encoded by exon 2 (PTHR1 GFP in Figure 1f ${ }^{19}$. We also used a version of PTHR1 in which yellow fluorescent protein (YFP) replaces the entire extracellular domain $\left(P T H R 1_{Y F P A E C D} \text {, Figure 1e }\right)^{20}$. Finally, we generated a construct that encodes a PTHR1 variant in which a 14-residue fragment from exon 2 was replaced with a 14-mer epitope tag from the intracellular protein UBC6e (PTHR1 6 E, Figure 1d) ${ }^{21}$. 

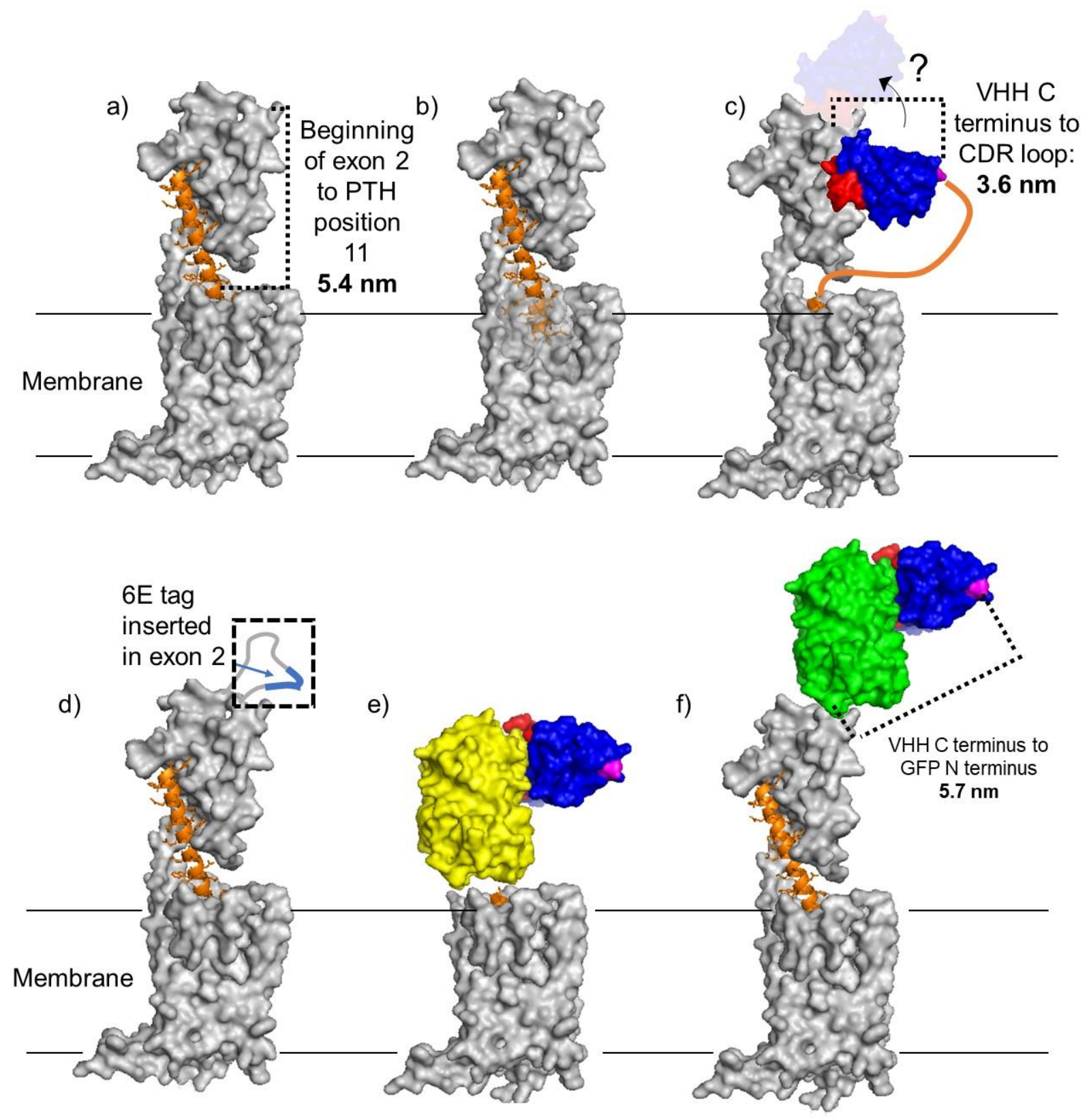

Figure 1: Schematic of VHH-mediated delivery of PTHR ligands and the constructs used in this study. (a) Crystal structure of human PTHR1 (silver) bound to PTH(1-34) (orange) protein data bank entry (PDB): 6FJ3. (b) Structure as in panel a but with PTHR1 residues 231296 and 349-353 shown in transparency to allow visualization of the N-terminal portion of PTH inserted into the transmembrane domain. (c) Modeled complex of PTHR1 with VHH-PTH(1-11). The $\mathrm{VHH}$ structure (blue) is based on VHHGFp from PDB: $3 \mathrm{~K} 1 \mathrm{~K}$ and $\mathrm{PTH}(1-11)$ bound to receptor (orange) from PDB: 6FJ3. The VHH is colored blue except for the complementarity determining loops (red), which bind the target, and the $\mathrm{C}$ terminus (magenta), where the PTH fragment is attached. Neither the site of binding for $\mathrm{VHH}_{\mathrm{PTHR}}$, nor is its orientation relative to PTHR1 is known, as indicated by the ghost version of the VHH. Modeled structures of (d) PTHR1 ${ }_{6 E},(\mathbf{e})$ PTHR1 YFP $\triangle E C D$, and (f) PTHR1 $1_{\text {GFP. }}$ (d) The predicted location of the PTHR1 
segment encoded by exon 2 is highlighted in the dashed box. The orientations of the inserted tags (6E-blue, YFP-yellow, GFP-green) relative to the remainder of the receptor are not known. (e) Residues 31-179 from PTHR1 and residues 12-34 from PTH (PDB: 6FJ3) were removed to provide this structure. (e-f) PTHR1 $1_{\text {YFP } \triangle E C D}$ and PTHR1 $1_{\text {GFP }}$ are depicted in complex with VHHGFP (blue; PDB 3K1K). (f) The distance constraint imposed by introduction of the GFP/YFP-VHH pair is highlighted here.

To target these receptors, we constructed conjugates comprised of $\mathrm{N}$-terminal fragments of PTH and VHHs (Figure 1). We used VHHs that recognize green or yellow fluorescent proteins $\left(\mathrm{VHH}_{\mathrm{GFP}}\right)^{22}$, a 14-mer peptide fragment from the intracellular protein UBC6e $\left(\mathrm{VHH}_{6 \mathrm{E}}\right)^{21}$, or PTHR1 itself $\left(\mathrm{VHH}_{\mathrm{PTHR}}\right)^{23}$. We expressed C-terminally His-tagged VHHs in bacteria in a form amenable to subsequent site-specific functionalization at the $\mathrm{C}$ terminus, using sortase $\mathrm{A}$ mediated labeling (sortagging) 24,25 . To these $\mathrm{VHHs}$ we attached either a triglycine-modified fluorophore for cytofluorimetry or a peptide with azide and biotin moieties for biorthogonal chemistry and conjugate tracking, respectively (Figure 2).

a) $\operatorname{PTH}(1-9)$ : AVUEIQLMHC

PTH (1-10): AVUEIQLMHQC

PTH (1-11): AVUEIQLMHQRC

PTH (1-14): AVUEIQLMHQRAKWC

PTH (1-34) : SVSEIQLMHNLGKH (15-34) C

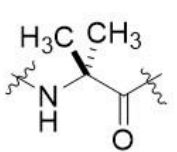

Aib (U)

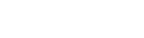

b)

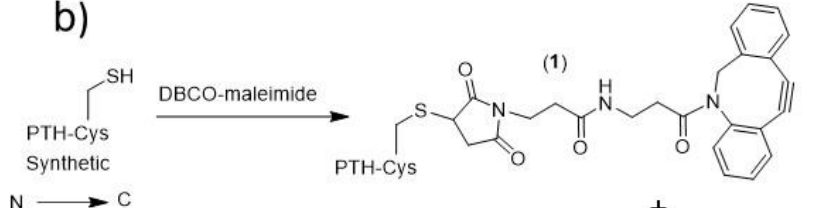

$\mathrm{N} \longrightarrow \mathrm{C}$

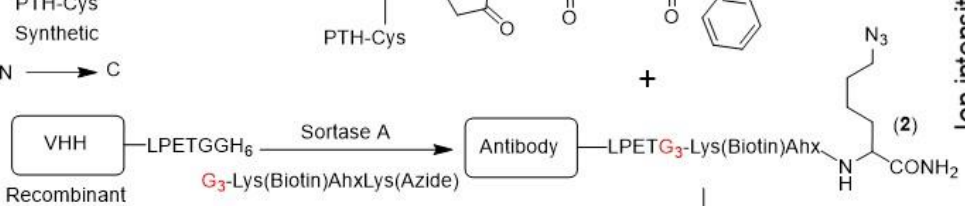

C)
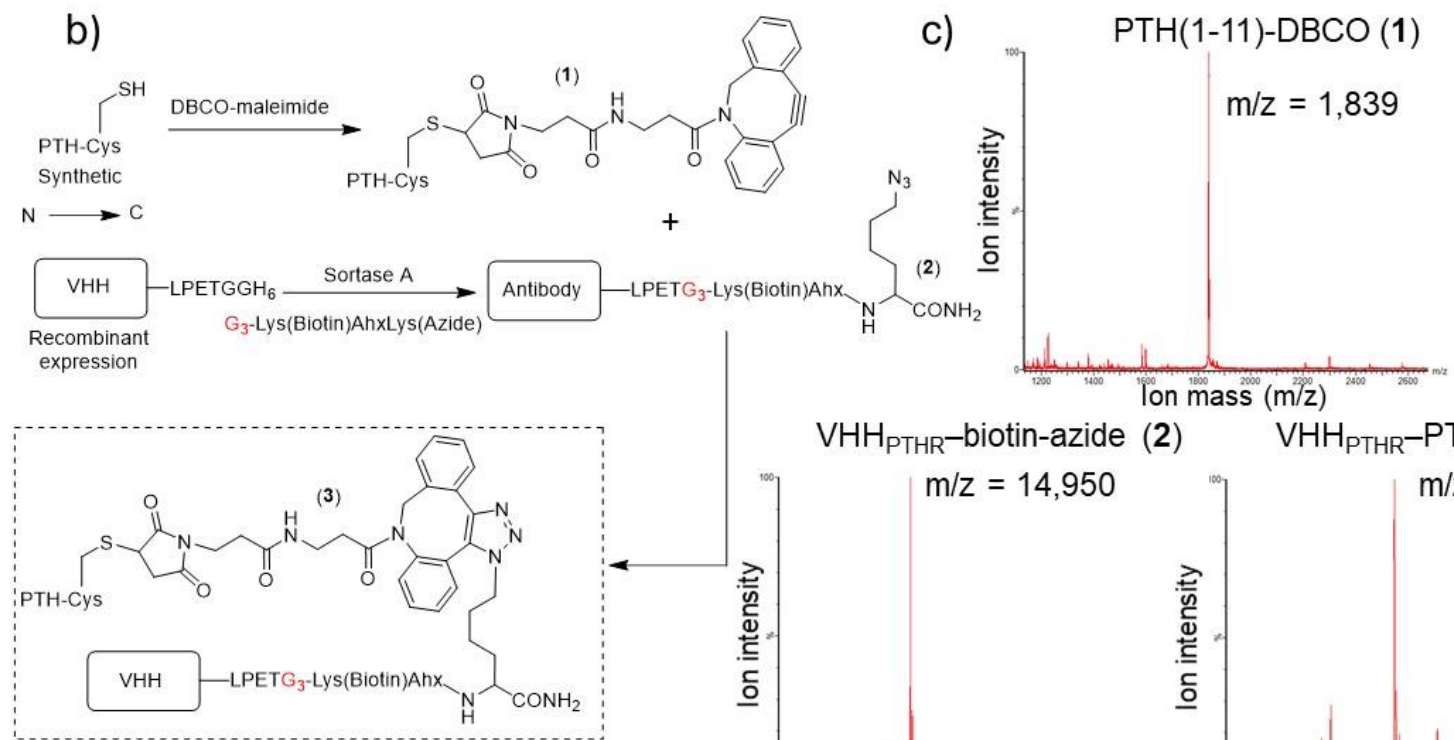

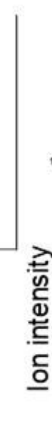

$\mathrm{VHH}_{\text {PTHR }}-\mathrm{PTH}(1-11)(3)$

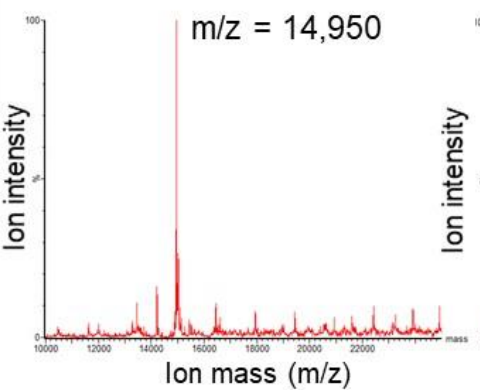

$\mathrm{m} / \mathrm{z}=16,790$

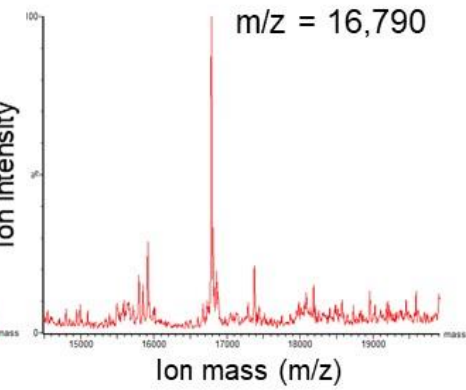


Figure 2: Synthetic peptides and conjugation strategy. (a) Structure of synthetic peptides used in this study. Residues that differ from human PTH and are derived from the M-PTH structural series are shown in red ${ }^{26}$. The residue denoted "U" corresponds to aminoisobutyric acid (Aib), depicted at right. (b) Synthetic scheme used to prepare PTH-VHH C-to-C terminal fusions. (c) Mass spectra from the preparation of $\mathrm{VHH}_{\mathrm{PTHR}}-\mathrm{PTH}(1-11)$ conjugates. Complete lists of mass spectral data for peptides and conjugates are found in Supporting Figures 1 and 2.

We determined whether VHHs bound to their intended targets on live cells by flow cytometry

(Figure 3a). We stained HEK293 cell lines stably transfected with the PTHR1 variants described above, rat PTHR1 (rPTHR1) 27, or PTHR2. Each of the VHHs stained the expected cell lines, with the exception of the VHH $\mathrm{VHFP}_{\mathrm{GTHR}} 1_{\mathrm{GFP}}$ pair. While the $\mathrm{VHH} \mathrm{HFP}_{\mathrm{GP}}$ used here binds both GFP and YFP ${ }^{22}$, at $100 \mathrm{nM}$ it only weakly stained HEK293 cells stably expressing PTHR1 $1_{\mathrm{GFP}}$. This weak staining is likely related to the inability of $\mathrm{VHH}_{\text {GFP }}$ to tightly bind the $\mathrm{pH}$-sensitive GFP variant known as pHluorin2 engrafted into the receptor ${ }^{19}$. $\mathrm{VHH}_{\mathrm{PTHR}}$ bound all constructs that retained the PTHR1 ECD, including rat PTHR1, but not PTHR1 YFP $\triangle E C D$. This places the binding site primarily in the PTHR1 extracellular domain (ECD). Only VHHGFP stained cells that express PTHR1 $1_{Y F P E C D}$, consistent with its ability to bind YFP ${ }^{22}$. None of the VHHs tested stained the cell line that expresses $\mathrm{PTHR}^{28}$. To estimate the affinity of the selected $\mathrm{VHH}$ for their targets we used flow cytometry to quantify binding. The staining of PTHR1 YFP-del-NT by VHH $\mathrm{VHFP}_{\text {and }}$ PTHR1 $1_{6 \mathrm{E}}$ by $\mathrm{VHH}_{6 \mathrm{E}}$ exhibited half-maximal staining at less than $10 \mathrm{nM}$, whereas the staining of cells expressing each of the PTHR1 receptor constructs that retained the ECD reached halfmaximal staining at 100-200 nM (Supporting Figure 3).
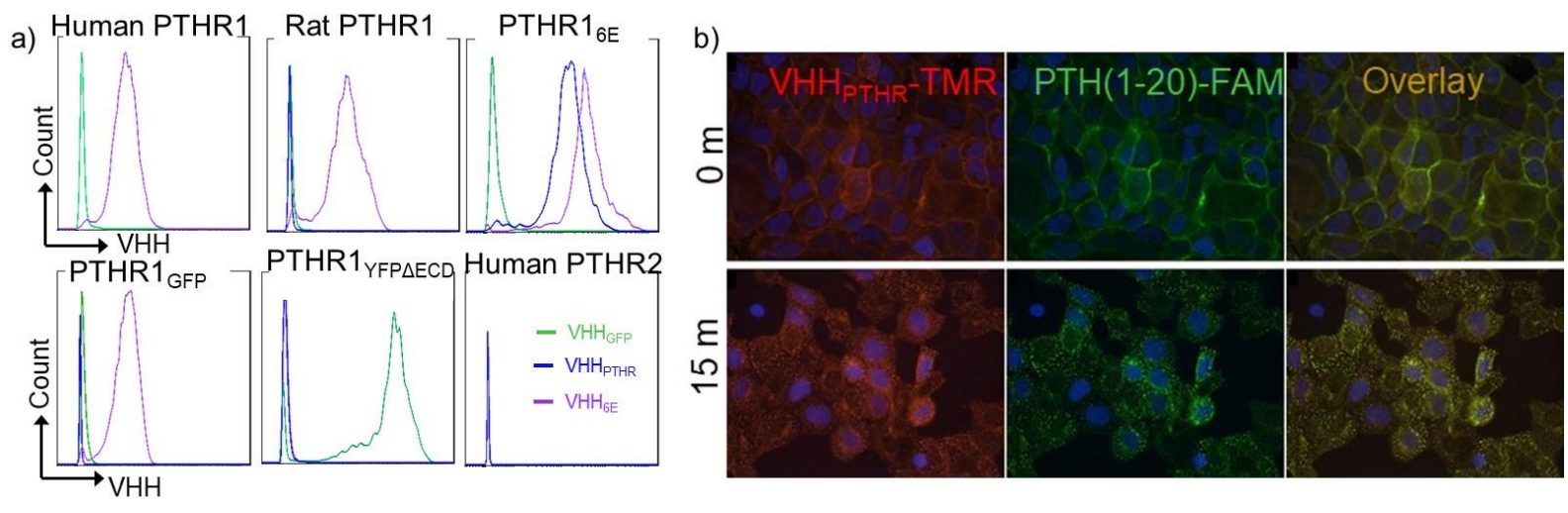
Figure 3: Binding of VHHs to HEK293 cell lines stably transfected with PTHRs. (a) Analysis of $\mathrm{VHH}$ binding to PTHR1, PTHR2 and variants by flow cytometry. HEK293 cell lines in suspension were incubated on ice with $100 \mathrm{nM}$ VHH sortagged with Alexafluor647, pelleted by centrifugation, washed and analyzed. (b) Analysis of $\mathrm{VHH}$ binding with microscopy. Adherent HEK293 cells expressing human PTHR1 were stained on ice with $50 \mathrm{nM} \mathrm{VHH}$ PTHR$^{-}$ tetramethylrhodamine (TMR) and $30 \mathrm{nM} \mathrm{PTH}(1-20)$-fluorescein (FAM) for 30 minutes. Following staining, cells were washed and treated with fixative in preparation for image acquisition either immediately after staining $(0 \mathrm{~m})$ or following a 15-minute incubation in medium at room temperature $(15 \mathrm{~m})$.

We used microscopy to complement these flow cytometry experiments and visualized trafficking of either PTHR1 or PTHR1 ${ }_{6 \mathrm{E}}$ following engagement by $\mathrm{PTH}(1-20)$ functionalized with fluorescein and either VHH $\mathrm{PTHR}_{\text {or }} \mathrm{VHH}_{6 \mathrm{E}}$ tagged with tetramethylrhodamine (Figure 3b, Supporting Figure 4). Imaging of cells fixed immediately after staining on ice shows colocalization of VHH and PTH at the cell surface. Following a 15-minute incubation at room temperature, we observed punctate and colocalized fluorescent signals, corresponding to endocytosed receptor-PTH-VHH complexes $^{29}$. Such colocalization indicates that the VHHs used and PTH(1-20) can simultaneously engage the receptor.

Peptide ligands of PTHR1 and conjugation to antibody fragments. To test whether delivery of PTH fragments to their site of action by conjugation to VHHs affects their signaling activity we synthesized N-terminal fragments of PTH (Figure 2, Table 1, Supporting Figure 5). These fragments were prepared as C-terminal amides by conventional solid-phase peptide synthesis, purified, and their identities were confirmed by mass spectrometry (Figure 2, Supporting Figure 1). Most of these peptides contained several of the modifications found in the M-PTH series of peptides, including the non-standard residue aminoisobutyric acid (Aib) at position 3, which enhances the biological activity of these short PTH fragments (Figure 2$)^{26}$. Each of these peptides contained a C-terminal cysteine (Cys). Using Cys-maleimide chemistry we appended a dibenzylcyclooctyne (DBCO) handle (Supporting Figure 1) to enable an azide-alkyne conjugation between the C-termini of azide-functionalized VHHs and DBCO-modified synthetic peptides. The composition of the conjugates was confirmed by mass spectrometry (Figure 2 , 
Supporting Figure 2). We also prepared conjugates in which a PTH(1-14) analogue with an Nterminal triglycine extension $\left(\mathrm{G}_{3}-\mathrm{PTH}(1-14)\right)$ was conjugated to $\mathrm{VHHs}$ using sortagging (Supporting Figure 6).

We then assessed the capacity of these peptides and conjugates to stimulate the production of cyclic adenosine monophosphate (CAMP), a second messenger molecule produced upon PTHR1 activation, using HEK293 cells expressing a targeted PTHR variant and a luciferasebased cAMP-responsive reporter ${ }^{30}$. Progressive truncation of C-terminal residues from PTH(134) caused a marked loss in the potency on wild-type PTHR1 and other PTHR1 variants with intact ECDs (Table 1, Supporting Figure 5). Addition of a triglycine appendage at the $\mathrm{N}$-terminus of $\mathrm{PTH}(1-14)$ caused a reduction in potency, relative to $\mathrm{PTH}(1-14)$ with a free $\mathrm{N}$-terminal amine (Supporting Figure 6), in line with precedent ${ }^{31}$. Conjugates in which $\mathrm{G}_{3}-\mathrm{PTH}(1-14)$ was ligated to the VHH C-terminus using sortase were completely inactive, emphasizing the importance of a free N-terminus for PTH (Supporting Figure 6). In contrast, conjugates formed by C-to-Cterminal fusion were active (Table 1, Supporting Figure 5).

\begin{tabular}{|c|}
\hline Peptide or conjugate \\
\hline PTH(1-34) \\
\hline РTH(1-14) \\
\hline PTH(1-11) \\
\hline РTH(1-10) \\
\hline PTH(1-9) \\
\hline $\mathrm{VHH}_{\mathrm{PTHR}}-\mathrm{PTH}(1-14)$ \\
\hline $\mathrm{VHH}_{\mathrm{PTHR}}-\mathrm{PTH}(1-11)$ \\
\hline $\mathrm{VHH}_{\mathrm{PTHR}}-\mathrm{PTH}(1-10)$ \\
\hline $\mathrm{VHH}_{6 \mathrm{E}}-\mathrm{PTH}(1-14)$ \\
\hline $\mathrm{VHH}_{6 \mathrm{E}}-\mathrm{PTH}(1-11)$ \\
\hline $\mathrm{VHH}_{6 \mathrm{E}}-\mathrm{PTH}(1-10)$ \\
\hline $\mathrm{VHH}_{6 \mathrm{E}}-\mathrm{PTH}(1-9)$ \\
\hline $\mathrm{VHH}_{\mathrm{GFP}}-\mathrm{PTH}(1-14)$ \\
\hline $\mathrm{VHH}_{\mathrm{GFP}}-\mathrm{PTH}(1-11)$ \\
\hline $\mathrm{VHH}_{\mathrm{GFP}}-\mathrm{PTH}(1-10)$ \\
\hline $\mathrm{VHH}_{\mathrm{GFP}}-\mathrm{PTH}(1-10)$ \\
\hline
\end{tabular}

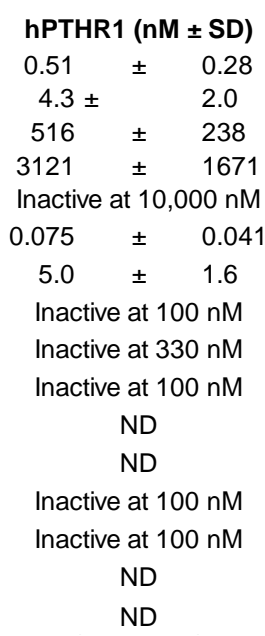

\begin{tabular}{|c|c|c|}
\hline \multicolumn{3}{|c|}{ PTHR1 $1_{\text {GFP }}$} \\
\hline 0.4 & \pm & 0.8 \\
\hline 2.3 & \pm & 1.2 \\
\hline 79 & \pm & 45 \\
\hline 2552 & \pm & 653 \\
\hline \multicolumn{3}{|c|}{ Inactive at $10,000 \mathrm{nM}$} \\
\hline 0.5 & \pm & 0.2 \\
\hline 0.5 & \pm & 0.1 \\
\hline \multicolumn{3}{|c|}{ ND } \\
\hline \multicolumn{3}{|c|}{ ND } \\
\hline \multicolumn{3}{|c|}{ Inactive at $100 \mathrm{nM}$} \\
\hline \multicolumn{3}{|c|}{ Inactive at $100 \mathrm{nM}$} \\
\hline \multicolumn{3}{|c|}{ ND } \\
\hline 1.8 & \pm & 0.6 \\
\hline 8.0 & \pm & 3.4 \\
\hline \multicolumn{3}{|c|}{ Inactive at $100 \mathrm{nM}$} \\
\hline \multicolumn{3}{|c|}{ Inactive at $100 \mathrm{nM}$} \\
\hline
\end{tabular}

\begin{tabular}{|c|c|c|}
\hline \multicolumn{3}{|c|}{ PTHR1 6 6E } \\
\hline 1.3 & \pm & 1.0 \\
\hline 3.4 & \pm & 1.6 \\
\hline 94 & \pm & 74 \\
\hline 5079 & \pm & 407 \\
\hline \multicolumn{3}{|c|}{ Inactive at $10,000 \mathrm{nM}$} \\
\hline 0.2 & \pm & 0.1 \\
\hline 4.0 & \pm & 3.2 \\
\hline \multicolumn{3}{|c|}{ ND } \\
\hline 0.4 & \pm & 0.2 \\
\hline 6.9 & \pm & 2.6 \\
\hline 2.8 & \pm & 1.4 \\
\hline \multicolumn{3}{|c|}{ Inactive at $100 \mathrm{nM}$} \\
\hline \multicolumn{3}{|c|}{ Inactive at $100 \mathrm{nM}$} \\
\hline \multicolumn{3}{|c|}{ Inactive at $100 \mathrm{nM}$} \\
\hline & ND & \\
\hline & ND & \\
\hline
\end{tabular}

\begin{tabular}{|c|c|c|}
\hline \multicolumn{3}{|c|}{ hPTHR1 $1_{\text {YFP }}$ ECD } \\
\hline 689 & \pm & 301 \\
\hline 1.1 & \pm & 0.9 \\
\hline 246 & \pm & 133 \\
\hline 3841 & \pm & 1604 \\
\hline \multicolumn{3}{|c|}{ Inactive at $10,000 \mathrm{nM}$} \\
\hline 0.9 & \pm & 0.5 \\
\hline \multicolumn{3}{|c|}{ Inactive at $100 \mathrm{nM}$} \\
\hline \multicolumn{3}{|c|}{ ND } \\
\hline \multicolumn{3}{|c|}{ ND } \\
\hline \multicolumn{3}{|c|}{ Inactive at $100 \mathrm{nM}$} \\
\hline \multicolumn{3}{|c|}{ ND } \\
\hline \multicolumn{3}{|c|}{ ND } \\
\hline 0.58 & \pm & 0.29 \\
\hline 0.14 & \pm & 0.06 \\
\hline 0.46 & \pm & 0.22 \\
\hline
\end{tabular}

Table 1: Stimulation of PTHR1 and variants by VHH-PTH conjugates. HEK293 cell lines were treated with varied doses of the indicated peptides or conjugates and activation was assessed by measuring luminescence from a cAMP-activated luciferase variant. Values listed represent $\mathrm{EC}_{50}$ values (mean $\pm \mathrm{SD}$ ). Each value comes from $\geq 3$ independent experiments. Further details, including the number of replicates for each measurement and the normalized maximal responses induced, are reported in Supporting Table 1. "ND" indicates that the 
measurement was not made. "Inactive" indicates that the luminescence response measured at that concentration was less than $5 \%$ of the maximal response induced for that cell line. ${ }^{\text {aThe }}$ precise $\mathrm{EC}_{50}$ value could not be obtained but at the highest concentration tested $(100 \mathrm{nM})$ this compound induced a response approximately $40 \%$ that of the maximal response observed.

The conjugation of PTH fragments lacking residues 15-34, known to be important for ECD binding, to $\mathrm{VHHs}$ that bound to the targeted receptor enhanced potency (Table 1). $\mathrm{VHH}_{6 \mathrm{E}^{-}}$ $\mathrm{PTH}(1-10)$ is 1,800 -fold more potent than PTH(1-10) on PTHR1 $1_{6 E}$, and $\mathrm{VHH}_{\mathrm{GFP}}-\mathrm{PTH}(1-10)$ is 7,800-fold more potent than PTH(1-10) on PTHR1 YFP $\triangle E C D$. The potency of VHHGFP-PTH(1-10) at PTHR1 YFPAECD $\left(\mathrm{EC}_{50} \sim 0.5 \mathrm{nM}\right)$ is especially notable given that $\mathrm{PTH}(1-34)$, an analogue with properties similar to naturally occurring $\mathrm{PTH}$, is relatively weakly active $\left(\mathrm{EC}_{50}>500 \mathrm{nM}\right)$ on this receptor. $\mathrm{VHH}_{\text {GFP }} \mathrm{PTH}(1-9)$ is active at $100 \mathrm{nM}$ on $\mathrm{PTHR} 1_{\text {YFPAECD }}$, whereas $\mathrm{PTH}(1-9)$ itself was inactive at 10,000 nM on all constructs tested. Similar trends are seen with larger PTH fragments. $\mathrm{VHH}_{6 \mathrm{E}}-\mathrm{PTH}(1-11)$ is 23-fold more potent than $\mathrm{PTH}(1-11)$ at $\mathrm{PTHR} 1_{6 \mathrm{E}}$ and $\mathrm{VHH}_{\mathrm{GFP}}$ $\mathrm{PTH}(1-11)$ is 1,800-fold more potent than PTH(1-11) at PTHR1 YFP $\triangle E C D$. VHHPTHR conjugation also increases the potency of $\mathrm{PTH}(1-11)$ and $\mathrm{PTH}(1-14)$ at PTHR1, PTHR1 $1_{G F P}$, and PTHR1 $1_{6 E}$, in line with results from $\mathrm{VHH}$ binding experiments. Even $\mathrm{VHH}$ that showed weak staining of the relevant cell lines, like that of $\mathrm{VHH}_{\mathrm{GFP}}$ on $\mathrm{PTHR}$ GFP expressing cells, still enhanced the signaling activity of $\mathrm{N}$-terminal fragments like $\mathrm{PTH}(1-11)$ upon conjugation. $\mathrm{VHH}_{\mathrm{GFP}}-\mathrm{PTH}(1-11)$ is

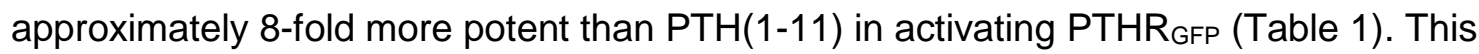
contrasts with the lack of signaling activity of $\mathrm{VHH}_{\mathrm{GFP}} \mathrm{PTH}(1-10)$ on $\mathrm{PTHR} 1_{\mathrm{GFP}}$ and $\mathrm{VHH}_{\mathrm{PTHR}}{ }^{-}$ PTH(1-10) on PTHR1, which likely relates to combining weakly active PTH fragments with VHHs that bind to receptors with lower affinity. Signaling duration, as assessed using a previously validated method $26,28,32$, is also prolonged for the shorter PTH fragments upon their conjugation to the appropriately specific VHH (Supporting Figure 7). The kinetics of the cAMP signaling induced by some VHH-PTH fragments resemble that seen with $\mathrm{PTH}(1-34)$ (Supporting Figure 7). 
In contrast to the increase in signaling activity provided by the conjugation of PTH fragments with receptor binding VHHs, conjugation of active PTH fragments with irrelevant VHHs is detrimental. For example, conjugates of $\mathrm{VHH}_{6 \mathrm{E}}$ and $\mathrm{VHH}_{\text {GFP }}$ with $\mathrm{PTH}(1-11)$ and $\mathrm{PTH}(1-14)$ are inactive on wild-type human PTHR1 at the highest concentrations tested, even though the peptides themselves are quite active (Table 1, Supporting Figure 5). This loss of activity is caused at least in part by a loss in receptor binding for PTH fragments conjugated to irrelevant VHHs (Supporting Figure 8). VHH 6 E-PTH(1-14) fails to bind hPTHR1 expressing cells whereas

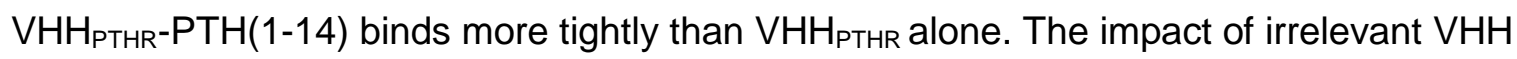
conjugation is not explained by variation in signaling activity caused by the chemical handles installed for azide-alkyne conjugation chemistry (Supporting Figure 9). Furthermore, the length of the VHH-PTH linker is not a strong determinant of conjugate signaling activity or specificity: incorporation of a $\mathrm{PEG}_{3}$ linker has minimal impact (Supporting Figure 9). The enhancements in signaling activity provided by VHH conjugation is not seen with PTHR1 ligands that retain their ECD binding element: conjugates of $\mathrm{PTH}(1-34)$ and VHHs retain potent biological activity regardless of whether the target of the VHH is present on the cell line tested, at least at

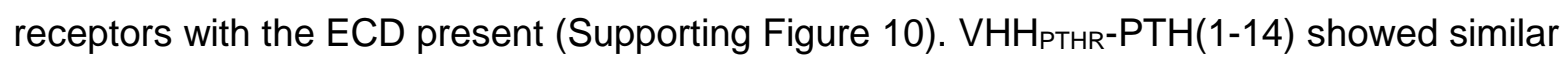
behavior at PTHR1 YFPAECD (Table 1).

The increase in biological activity and selectivity of PTH fragments seen through conjugation to VHHs led us to test whether the same enhancements in activity applied to two naturally occurring subtypes of PTHR. PTH(1-34) tightly binds and activates both PTHR1 and PTHR2 ${ }^{8}$. VHHPTHR binds to PTHR1 but not PTHR2 (Figure 3). VHH PTHR-PTH conjugates should therefore activate PTHR1 but not PTHR2. We focused on conjugates of PTH(1-14) as this fragment also activated PTHR1 and PTHR2 (Figure 4). The VHHPTHR-PTH(1-14) conjugate activated PTHR1 more potently than any other compound tested in this study $\left(\mathrm{EC}_{50} \sim 0.07 \mathrm{nM}\right)$, whereas it was completely inactive at PTHR2 at $330 \mathrm{nM}(>4,500$-fold selectivity for PTHR1, Figure 4). This 
contrasts with the lack of selectivity of $\mathrm{PTH}(1-34)$ in this study (5-fold selectivity for PTHR1) and in past work ${ }^{8}$.

a)

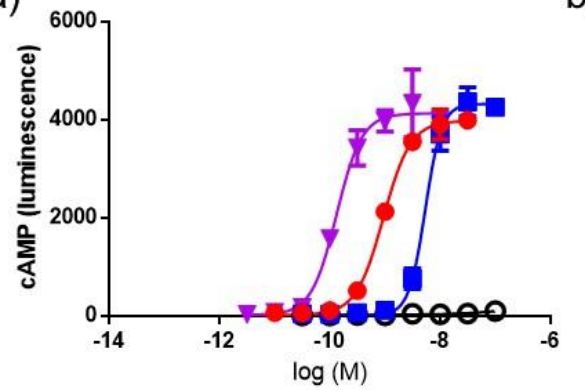

c) Ligand

$\mathrm{PTH}(1-34)$

$\mathrm{PTH}(1-14)$

$\mathrm{VHH}_{\mathrm{PTHR}}-\mathrm{PTH}(1-14$

$\mathrm{VH} \mathrm{H}_{6 \mathrm{E}}-\mathrm{PTH}(1-14)$ b)

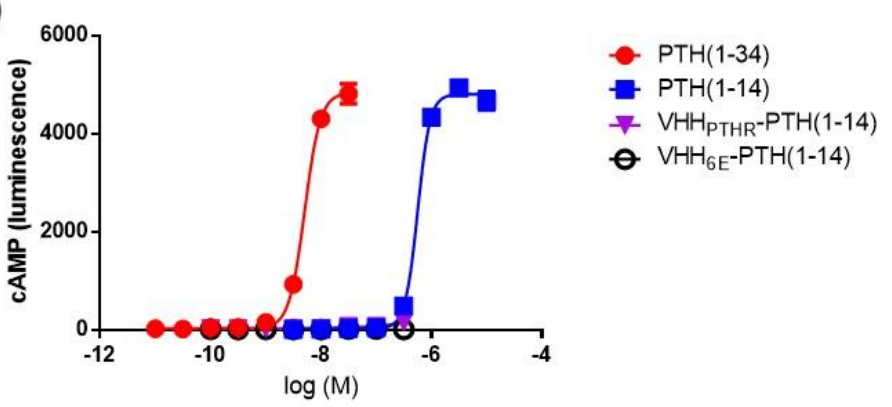

hPTHR1 (EC 50, nM)

$\begin{array}{ccc}0.31 & \pm & 0.16 \\ 3.5 & \pm & 1.3 \\ 0.071 & \pm & 0.044 \\ \text { Inactive } & \text { at } 330 \mathrm{nM}\end{array}$

hPTHR2

$1.45 \quad \pm \quad 2.42$

$924 \pm 328$

Inactive at $330 \mathrm{nM}$

Inactive at $330 \mathrm{nM}$

Figure 4: Selective and potent activation of PTHR1 via VHHPTHR conjugation. HEK293 cell lines stably expressing either human PTHR1 (hPTHR1) or hPTHR2 were treated with varied doses of the indicated peptides or conjugates and activation was assessed by cAMP production. (a-b) Representative dose-response curves for (a) hPTHR1 or (b) hPTHR2 activation. Data points indicate mean \pm SD. Curves result from fitting of a sigmoidal doseresponse model to data. (c) Tabulation of cAMP induction potencies. Data for hPTHR1 are identical to those in Table 1 and are included here for comparison. Values listed represent $\mathrm{EC}_{50}$ values (mean $\pm \mathrm{SD}$ ). Each value comes from $\geq 3$ independent experiments. Further details, including the number of replicates for each measurement $(n)$, are reported in Supporting Table 1.

In vivo activity. We tested whether the potent biological activity observed for VHH-PTH conjugates in cell-based assays would extend to an in vivo setting. We used the $\mathrm{VHH}_{\mathrm{PTHR}^{-}}$ PTH(1-14) conjugate in these experiments because, unlike VHH $\mathrm{PTHR}_{\mathrm{P}} \mathrm{PTH}(1-11)$, it stimulated signaling though the Gq/PLC signaling pathway in cells expressing human PTHR1 (Supporting Figure 11). Indeed, $\mathrm{VHH}_{\mathrm{PTHR}}$ also potentiated $\mathrm{PTH}(1-11)$ signaling activity for the rat PTHR1 (Supporting Figure 12). Since VHH would also bind mouse PTHR1, as these receptors are quite similar (99\% identical in their extracellular domain). To measure in vivo activity, we injected mice subcutaneously with equimolar amounts of either $\mathrm{PTH}(1-34), \mathrm{M}-\mathrm{PTH}(1-14)$, VHH $\mathrm{PTHR}^{-} \mathrm{PTH}(1-14)$, or saline. PTH(1- 
34) induces a strong increase in blood ionized calcium levels, which peaks $1-2 \mathrm{~h}$ after injection and returns to baseline thereafter, whereas free M-PTH(1-14) exhibits little if any activity in this assay, in line with past findings ${ }^{26}$. Our experiment showed that VHHPTHR-PTH(1-14) stimulated a spike in blood calcium that peaked two hours after injection (Figure 5). The conjugation of

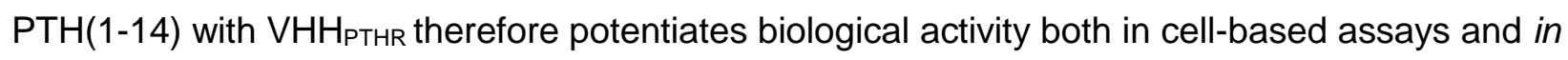
vivo.

a)

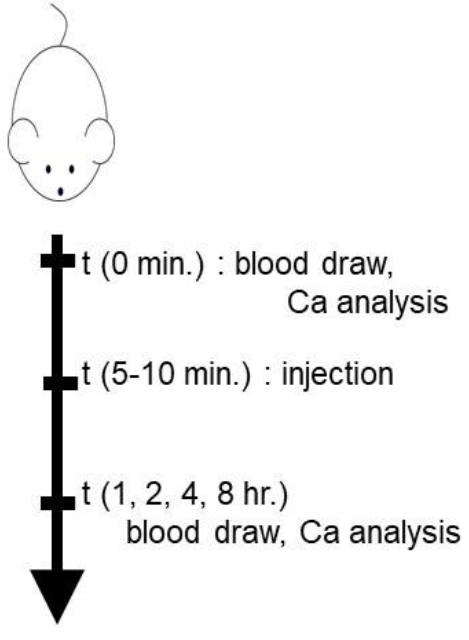

b)

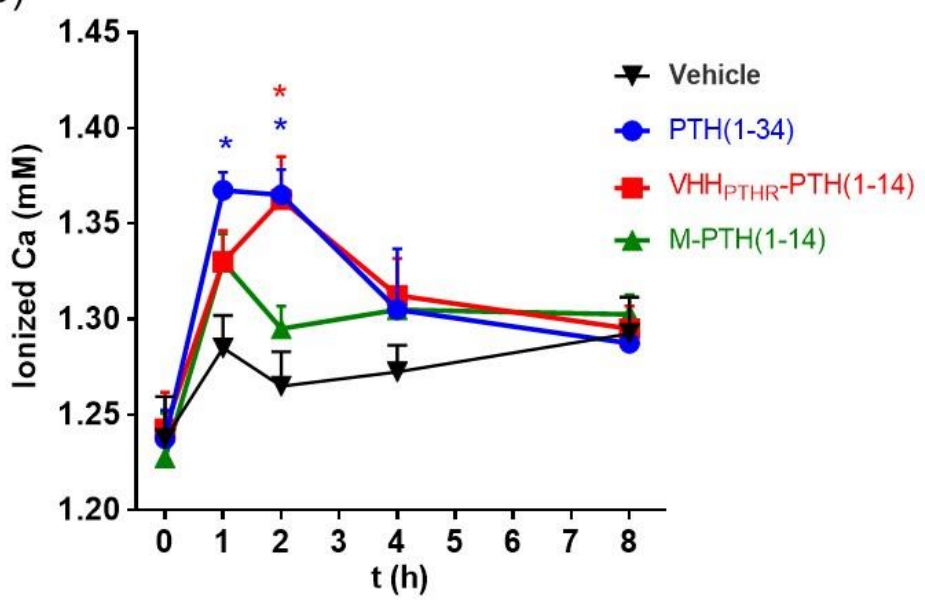

Figure 5. VHH conjugation potentiates an in vivo response. (a) Schematic of the experiment performed in mice. (b) Measurement of blood ionized calcium levels in mice injected with PTH and conjugates. Mice (CD1 females, 11 weeks) were injected subcutaneously with the indicated ligand (Dose $=35 \mathrm{nmol} / \mathrm{kg}$ ). Blood was drawn at the indicated time points and analyzed for ionized calcium levels. Data points indicate mean \pm standard error of the mean (SEM), $n=4$, * $p<0.05$ vs. vehicle. 
Discussion: Antibodies as part of conventional antibody-drug conjugates deliver cytotoxic compounds that typically target intracellular proteins ${ }^{1,2}$. Less explored is the use of antibodies to deliver ligands for surface receptors, such as GPCRs. This is likely due in part to complications in preparing homogenous and bioactive conjugates of antibodies and ligands that rely on antibody binding to potentiate engagement of receptor by the ligand. The immunocytokines (conjugates of cytokines and antibodies) are an exception ${ }^{33}$. Immunocytokines have been characterized in cell- and animal-based models and have progressed to the clinic, but not without toxicity, suggesting an insufficiency in targeting ${ }^{33}$. In one case, even the identity of the targeting antibody of the immunocytokine was irrelevant for in vivo efficacy ${ }^{34}$. The introduction of mutations in cytokines to improve the selectivity of immunocytokines can dampen the affinity of cytokines for their receptors ${ }^{35,}{ }^{36}$. Immunocytokine-based approaches differ from the CLAMP platform in that they rely on genetic fusions (and genetically encoded residues) and the use of full-size cytokine domains, as opposed to the small peptide fragments with non-natural residues used here.

In one precedent for targeting GPCRs with antibody-ligand fusions, VHH $\mathrm{GFP}_{\text {equipped with a }}$ SNAP-tag was linked to a photoactivatable ligand for the GPCR mGluR2 ${ }^{37}$. This fusion was then used to activate a GFP-tagged receptor upon photoactivation of the ligand. The response induced by a saturating solution of the photoactivatable $\mathrm{VHH}$-ligand conjugate was $\sim 40 \%$ as strong as that induced by a saturating solution of natural ligand and moreover required the use of a receptor-GFP fusion ${ }^{37}$. This precluded the use of genetically unmodified cells or animals. In another example, full-length anti-PKSK9 antibodies fused at the N-terminus of the heavy or light chain with analogues of the glucagon-like peptide 1 (GLP-1) were produced ${ }^{38}$. However, most of the fusions tested were expressed in low yield, isolated with inactivating truncations in the GLP1 fragment, unstable in solution, or were degraded rapidly in vivo, demonstrating the difficulties 
encountered when expressing fusion proteins comprised of full-length antibodies and ligands of interest ${ }^{38}$.

Despite several screening campaigns, no VHHs that directly activate GPCRs have been identified $^{5}$. We prepared a library of C-to-C terminal fusions of VHHs and synthetic PTH peptides. The necessity for the generation of $\mathrm{C}$-to- $\mathrm{C}$ fusions is supported by the lack of activity of the corresponding N-to-C fusions (Supporting Figure 6). A further benefit of our synthetic strategy is the ease of incorporation of non-natural residues such as Aib into the synthetic peptide portion of the conjugate to improve proteolytic stability ${ }^{38}$. Several conjugates stimulated cAMP responses with potencies similar to that of $\mathrm{PTH}(1-34)$ (Table 1). Even $\mathrm{PTH}(1-9)$, which fails to activate PTHR1 unless tethered directly to the receptor's N-terminus via genetic fusion ${ }^{39}$, showed activity when conjugated to a $\mathrm{VHH}$ (Table 1). VHH-mediated delivery of ligands should enable identification of weak ligands that might otherwise be dismissed as completely inactive. Similar observations were made in evaluating conjugates consisting of peptide fragments derived from the $\mathrm{N}$ - and $\mathrm{C}$-termini of corticotrophin releasing factor-1, which were weakly active or inactive alone, but once assembled via click chemistry, several conjugates were potent agonists $^{40}$.

Agonist activity for $\mathrm{VHH}-\mathrm{PTH}$ conjugates was completely dependent on binding of the $\mathrm{VHH}$ to the receptor being targeted: a mismatch between specificity of the $\mathrm{VHH}$ and the receptor construct led to a loss in conjugate activity. We identified a conjugate, VHH PTHR $^{-P T H(1-14), ~ w i t h ~}$ very potent signaling activity in cell-based assays (Table 1), with biological activity in mice (Figure 5), and with selectivity for PTHR1 over PTHR2 that far surpasses the selectivity of PTH(1-34), the prototypical PTHR1 agonist (Figure 4) used clinically. Success in targeting PTHR1 over PTHR2 sets the stage for designing ligands that specifically activate other receptors with overlapping specificities ${ }^{6,7}$. 
The ability to deliver ligands to specific subtypes of receptors, or to receptors engineered to contain an antibody-recognized tag, should allow the creation of (modular) versions of designed receptors exclusively activated by designer drugs (DREADDs) ${ }^{41}$. Previously described DREADDs for GPCRs were identified through modification of the ligand binding site of naturally occurring GPCRs, so that the modified receptors respond to a "designer" small molecule but not the ligand of the prototype receptor. These designer molecules selectively activate the designer receptor but not any endogenously expressed alternative ${ }^{42,43}$. A similar approach has been deployed to produce an orthogonal receptor-ligand pair for interleukin-244. Our finding that $\mathrm{VHH}_{\text {GFP-PTH(1-11) potently activates PTHR1 }}$ YFPAECD $\left(\mathrm{EC}_{50} \sim 0.15 \mathrm{nM}\right)$ but is inactive at wild-type PTHR1, suggests a path towards using VHH-tag recognition as a way to convert a GPCR of choice into a DREADD. One aspect of GPCR pharmacology that has not been faithfully reproduced in some DREADD constructs is that of ligand binding kinetics ${ }^{45}$. For some receptors, such as PTHR1, the duration of ligand binding and the signaling induced as a consequence can dictate the type of physiological response evoked. The duration of the cAMP response elicited by PTHR1 activation is correlated with the strength of the calcemic response in vivo 26,46 . Several of the VHH-PTH conjugates tested here induce cAMP signaling that is prolonged relative to the free peptide and similar to that of PTH(1-34) (Supporting Figure 7), suggesting that the affinity provided by $\mathrm{VHH}$ binding can be used as an independent means to adjust ligand binding and signaling kinetics.

In conclusion, we show that the conjugation of suboptimal PTHR1 agonist peptides to VHHs that target the intended receptor provides a substantial increase in agonist potency and receptor selectivity. The ability to independently modulate receptor affinity. The structure of the agonist used to activate signaling should enable a further dissection of connections between ligand affinity, receptor signaling kinetics, and ligand bias ${ }^{47}$. The CLAMP platform is amenable to 
targeting other GPCRs, especially those with large peptide ligands that bind to their receptors via a two-site mechanism, such as family B GPCRs and chemokine receptors.

\section{ONLINE METHODS.}

General. HEK293 cell lines were cultured in DMEM medium supplemented with 10\% (v/v) fetal bovine serum and penicillin/streptomycin. Cell lines were routinely tested mycoplasma infection. LC/MS was performed on a Waters Xevo Q-Tof system equipped with HPLC-C8 columns. Mass spectra were obtained using Q-Tof mass spectrometry with a positive ionization mode. Masses for VHHs and conjugates were calculated via analysis of multiply charged ions using the MaxEnt feature on MassLynx software. Protein and peptide concentrations were calculated using absorption at $280 \mathrm{~nm}$ for VHHs and peptides with tryptophan (Trp) residues. For peptides without Trp, the amount of peptide was quantified gravimetrically assuming that the weighed mass consisted of $50 \%$ peptide (w/w).

Plasmids and DNA. Cell lines stably expressing human PTHR1, rat PTHR1, PTHR1 ${ }_{\mathrm{GFP}}$, and PTHR1 $1_{\text {YFP }}$ ECD along with a CAMP-responsive luciferase variant have been previously reported ${ }^{19}$, 20, 27. PTHR1 ${ }_{6 \mathrm{E}}$ was produced using the Q5 Site-directed mutagenesis kit (NEB). Annotated sequence data for PTHR1 ${ }_{6 \mathrm{E}}$ and alignment with $\mathrm{hPTHR} 1$ is found in Supporting Figure 13. The sequence of PTHR1 YFPAECD is shown in Supporting Figure 14. Materials are available upon request.

Peptide synthesis. Peptides were prepared using conventional solid-phase synthesis methods with Fmoc-protection of backbone amines. Synthesis was performed on Rink-amide linker resin to yield C-terminal amides. Backbone deprotection was performed via treatment with piperidine in dimethylformamide (DMF, 20\% vol/vol) for 15 minutes at room temperature. Coupling was

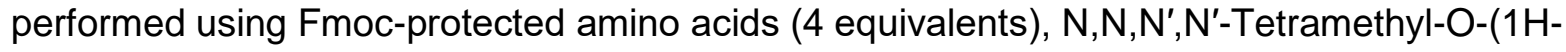
benzotriazol-1-yl)uronium hexafluorophosphate (HBTU, 4 equivalents), and 
diisopropylethylamine (DIPEA, 8 equivalents) in DMF for 45 minutes at room temperature. Fmoc-Lys(biotin)-OH and Fmoc-Lys(azide)-OH were from used from commercial sources without alteration the synthetic methods described above. Following completion of synthesis, the resin was dried and deprotection was carried out using a solution of $92.5 \%$ trifluoroacetic acid, $5 \% \mathrm{H}_{2} \mathrm{O}$, and $2.5 \%$ TIPS. Peptides were precipitated into diethyl ether, pelleted by centrifugation, dried under a stream of air, purified using reversed-phase C18 HPLC using a water-acetonitrile gradient, and lyophilized. The identity and approximate purity of peptides was confirmed by LC/MS (Supporting Figure 1). Purified products were dissolved in water (10 mM stock concentration) and stored at $-20^{\circ} \mathrm{C}$.

Purified peptides with C-terminal cysteines were subjected to a reaction with a 2-fold molar excess of either DBCO-maleimide (Click Chemistry Tools) or DBCO-PEG 3 -maleimide (ConjuProbe) (Supporting Figure 9) in solvent with 50\% (v/v) dimethylsulfoxide (DMSO) and 50 $\mathrm{mM} \mathrm{pH} \mathrm{7.4} \mathrm{phosphate} \mathrm{buffer} \mathrm{and} \mathrm{purified} \mathrm{by} \mathrm{reversed-phase} \mathrm{C18} \mathrm{HPLC.} \mathrm{The} \mathrm{identity} \mathrm{of}$ peptides was confirmed by LC/MS (Supporting Figure 1). Purified products were dissolved in DMSO (1 mM stock concentration) and stored at $-20^{\circ} \mathrm{C}$.

Protein expression and purification. The production and purification of $\mathrm{VHH}_{\mathrm{GFP}}$ (named $\mathrm{VHH}$ enhancer) and $\mathrm{VHH}_{6 \mathrm{E}}$ (named $\mathrm{VHH} 05$ ) has been described previously ${ }^{21,} 22$. The sequence for VHH ${ }_{\text {PTHR }}$ was acquired from the literature (named 22A3) ${ }^{23}$. Briefly, VHHs were expressed using the pHEN6 vector. Plasmids coding for PelB-VHH-LPETGG-His 6 were transformed into WK6 E.coli using heat shock. Transfected WK6 E. coli were grown in Luria Bertani broth under ampicillin selection at $37^{\circ} \mathrm{C}$ until an optical density at $600 \mathrm{~nm}$ between 0.6 and 0.8 was reached. Protein expression was induced by the addition of $1 \mathrm{mM} \mathrm{IPTG}$ and cells were grown at $30^{\circ} \mathrm{C}$ overnight. The bacteria were pelleted by centrifugation and resuspended in TES buffer (50 mM Tris, $650 \mu \mathrm{M}$ EDTA, $2 \mathrm{M}$ sucrose, $15 \mathrm{~mL}$ buffer per liter of culture) to prepare for osmotic shock. After incubating for 2 hours at $4{ }^{\circ} \mathrm{C}, 75 \mathrm{ml}$ distilled $\mathrm{H}_{2} \mathrm{O}$ was added, and the 
bacterial suspension was incubated overnight at $4{ }^{\circ} \mathrm{C}$. The bacteria were again pelleted and VHHs were purified from the supernatant by Ni-NTA bead batch purification, followed by buffer exchange. Sortase-A pentamutant was expressed and purified as previously described ${ }^{3}$.

Flow cytometry. Suspensions of cells in PBS were stained for 1 hour on ice in the presence of indicated concentrations of VHH probes functionalized with Alexafluor647. Cells were pelleted by centrifugation and washed with PBS prior to analysis by flow cytometry (BD Accuri C6). Gating was performed on forward scatter/side scatter profiles to analyze intact cells. Data was analyzed using FlowJo version 7.6. The median fluorescent intensity (MFI) of stained cells was used to generate $\mathrm{VHH}$ binding dose response curves (Supporting Figure 3).

Sortase-mediated labeling (sortagging). VHHs were labeled using sortase A pentamutant as described $^{25}$. Briefly, VHH $(20-100 \mu \mathrm{M})$ with a C-terminal sortase-recognition motif and His-tag were incubated with GGG-peptide $(500 \mu \mathrm{M})$ and sortase A pentamutant (10 $\mu \mathrm{M})$ in Tris-buffered saline (TBS) containing $10 \mathrm{mM} \mathrm{CaCl}_{2}$ overnight at $14^{\circ} \mathrm{C}$. Functionalized $\mathrm{VHH}$ were purified from unreacted VHH and sortase by exposure to nickel-NTA sepharose beads and removal of GGG-peptide by buffer exchange using a $10 \mathrm{kDa}$ molecular weight cutoff spin filter or a PD10 disposable size exclusion column. Purified VHH conjugates were concentrated using $10 \mathrm{kDa}$ spin filter. $\mathrm{VHH}-\mathrm{PTH}(1-14)$ and $\mathrm{VHH}_{-} \mathrm{G}_{3}-\mathrm{PTH}(1-14)$ conjugates were prone to precipitation following concentration.

VHH-peptide conjugation reactions. VHH-biotin-azide conjugates (Figure 2) were mixed with PTH-DBCO (3-fold molar excess) in TBS with 10\% (v/v) glycerol. The reaction was shaken at $22^{\circ} \mathrm{C}$ until unreacted $\mathrm{VHH}$-biotin-azide had been completely consumed. The product conjugate was purified from free PTH-DBCO using a PD10 size exclusion column. Product identity was confirmed by LC/MS (Supporting Figure 2). 
Microscopy. Monolayers of HEK293 cells grown on glass cover slips at approximately $80 \%$ confluency expressing either hPTHR1 or PTHR 6 E were washed with Hanks balanced salt solution supplemented with $10 \mathrm{mM} \mathrm{HEPES} \mathrm{pH} 7.4$ and $0.1 \%$ (w/v) bovine serum albumin (HB). The cells were then stained with M-PTH(1-20)-fluorescein and VHH-tetramethylrhoadmine in $\mathrm{HB}$ at $4^{\circ} \mathrm{C}$ for $30 \mathrm{~m}$. After staining, cells were washed with $\mathrm{HB}$ three times, and fixed with $4 \%$ formalin either immediately after rinsing or following a $15 \mathrm{~m}$ incubation at room temperature in DMEM $+10 \%$ FBS. Cells were then rinsed and mounted with Vector-shield containing DAPI (to visualize nuclei) on glass slides for imaging. Images were acquired using a Nikon Eclipse $\mathrm{Ni}$ system with a 40x PLAN FLUOR 0.75NA DIC M/N2 objective.

Measurement of cAMP response. These assays were performed as previously described ${ }^{27}$. Briefly, HEK-293-derived cell lines that stably express the Glosensor cAMP reporter (Promega Corp. $)^{30}$ and PTHR1, a PTHR1 variant, or PTHR2 were seeded into white sided 96 well plates (50,000 cells/well) and grown to confluency. Confluent monolayers of cells were pre-incubated with $\mathrm{CO}_{2}$ independent medium containing D-luciferin $(0.5 \mathrm{mM})$ at $37^{\circ} \mathrm{C}$ until a stable baseline level of luminescence was established (20 min). Varying concentrations of ligands were then added, and the time course of luminescence response was recorded using BioTek plate reader. The maximal luminescence response (observed 12-16 min after ligand addition) was used to construct dose-response data sets (Table 1, Supporting Figure 5).

For the measurement of CAMP signaling duration experiments (Supporting Figure 7) were performed as previously described ${ }^{28}$. Cells were treated with ligands at the indicated concentrations for 12 minutes (ligand-on phase). After this period, the medium in each well was removed and the cells were rinsed twice with $\mathrm{CO}_{2}$-independent medium to remove unbound 
ligand. After the addition of D-luciferin-containing fresh medium to each well, the luminescence was recorded for an additional 30-40 minutes (ligand-off phase).

Measurement of cytoplasmic calcium mobilization. The mobilization of $\mathrm{Ca}^{2+}$ levels was assessed in the HEK293 cell line stably transfected with human PTHR1. Intracellular $\mathrm{Ca}^{2+}$ levels were assessed using a cell-permeant $\mathrm{Ca}^{2+}$ sensor, Fura2-AM (Invitrogen). Cells in a black 96well plate were loaded with Fura2-AM in the presence of Pluronic F-127 for 45 min and then rinsed with Hanks buffered saline solution (HBSS). Following an additional 30-minute incubation in HBSS, the plate was analyzed using a PerkinElmer Life Sciences Envision plate reader to monitor fluorescence emission at a wavelength of $515 \mathrm{~nm}$, upon excitation at wavelengths of 340 and $380 \mathrm{~nm}$. The data were recorded at 2-second intervals prior to and after ligand addition. The data were calculated as the ratio of the fluorescence signal obtained with excitation at 340 $\mathrm{nm}$ to that obtained with excitation at $380 \mathrm{~nm}$.

Animal experiments and measurement of in vivo response. Mice (CD1 female, age 11 weeks) were treated in accordance with the ethical guidelines adopted by Massachusetts General Hospital. Calcemic response assays were conducted using cohort sizes comparable to past work ${ }^{27}$, which provided data adequate for identifying differences in the time course and magnitude of PTH-induced calcemic responses. Statistical analyses were performed assuming Gaussian distribution of data. Mice ( $n=4$ per compound) were injected subcutaneously with vehicle (10 mM citric acid/150 mM NaCl/0.05\% Tween-80, $\mathrm{pH} 5.0$ ) or vehicle containing PTH or conjugate at a dose of $35 \mathrm{nmol} / \mathrm{kg}$ body weight. Prior to injection, mice were grouped according to basal blood calcium concentrations to ensure each group possessed similar average (mean) blood ionized calcium levels at $t=0$. Blood was withdrawn just before injection $(t=0)$ or at times thereafter. Tail vein blood was collected and immediately analyzed. Blood $\mathrm{Ca}^{2+}$ concentration was measured with a Siemens RapidLab $348 \mathrm{Ca} 2+/ \mathrm{pH}$ analyzer. 
Data calculations. Data were processed using Microsoft Excel and GraphPad Prism 6. Data from cAMP dose-response assays were analyzed using a sigmoidal dose-response model with variable slope. Data sets were statistically compared by using Student's t test (two-tailed) assuming unequal variances for the two sets.

DATA AVAILABILITY: The data that support the findings of this study are available from the corresponding authors upon reasonable request.

AUTHOR CONTRIBUTIONS: The manuscript was written by RWC and HP. Conceptual input was provided by RWC, FAF, AWW, TG, and HLP. Experiments were designed and performed by RWC, FAF, ED, NS and TG.

COMPETING INTERESTS: RWC, TG and HLP have filed a provisional patent covering the use of VHH fusions for targeting GPCRs.

ACKNOWLEDGMENTS: Funding was provided by the National Institutes of Health grant numbers P01-DK011794 (TJG), P30-AR066261 (TJG), and R01-Al087879 (HLP). RWC is supported in part by funding from the Cancer Research Institute Irvington Postdoctoral Fellowship. AWW is supported by the Arnold O. Beckman Postdoctoral Fellowship.

\section{References.}

1. Carter, P. J.; Lazar, G. A., Next generation antibody drugs: pursuit of the 'high-hanging fruit'. Nature Reviews Drug Discovery 2018, 17 (3), 197-223.

2. Thomas, A.; Teicher, B. A.; Hassan, R. T., Antibody-drug conjugates for cancer therapy. Lancet Oncology 2016, 17 (6), E254-E262. 
3. Hauser, A. S.; Attwood, M. M.; Rask-Andersen, M.; Schioth, H. B.; Gloriam, D. E., Trends in GPCR drug discovery: new agents, targets and indications. Nature Reviews Drug Discovery 2017, 16 (12), 829-842.

4. Hutchings, C. J.; Koglin, M.; Olson, W. C.; Marshall, F. H., Opportunities for therapeutic antibodies directed at G-protein-coupled receptors. Nature Reviews Drug Discovery 2017, 16 (11), 787-+. 5. Heukers, R.; De Groof, T. W. M.; Smit, M. J., Nanobodies detecting and modulating GPCRs outside in and inside out. Current Opinion in Cell Biology 2019, 57, 115-122.

6. $\quad$ Scholten, D. J.; Canals, M.; Maussang, D.; Roumen, L.; Smit, M. J.; Wijtmans, M.; de Graaf, C.; Vischer, H. F.; Leurs, R., Pharmacological modulation of chemokine receptor function. British Journal of Pharmacology 2012, 165 (6), 1617-1643.

7. Bortolato, A.; Dore, A. S.; Hollenstein, K.; Tehan, B. G.; Mason, J. S.; Marshall, F. H., Structure of Class B GPCRs: new horizons for drug discovery. British Journal of Pharmacology 2014, 171 (13), 31323145.

8. Gardella, T. J.; Vilardaga, J.-P., International Union of Basic and Clinical Pharmacology. XCIII. The Parathyroid Hormone Receptors-Family B G Protein-Coupled Receptors. Pharmacological Reviews 2015, 67 (2), 310-337.

9. de Graaf, C.; Song, G. J.; Cao, C.; Zhao, Q.; Wang, M. W.; Wu, B. L.; Stevens, R. C., Extending the Structural View of Class B GPCRs. Trends in Biochemical Sciences 2017, 42 (12), 946-960.

10. Ingram, J. R.; Schmidt, F. I.; Ploegh, H. L., Exploiting Nanobodies' Singular Traits. Annual Review of Immunology, Vol 36 2018, 36, 695-715.

11. Koehl, A.; Hu, H. L.; Feng, D.; Sun, B. F.; Zhang, Y.; Robertson, M. J.; Chu, M.; Kobilka, T. S.; Laermans, T.; Steyaert, J.; Tarrasch, J.; Dutta, S.; Fonseca, R.; Weis, W. I.; Mathiesen, J. M.; Skiniotis, G.; Kobilka, B. K., Structural insights into the activation of metabotropic glutamate receptors. Nature 2019, 566 (7742), 79-+.

12. Konning, D.; Zielonka, S.; Grzeschik, J.; Empting, M.; Valldorfl, B.; Krah, S.; Schroter, C.; Sellmann, C.; Hock, B.; Kolmarl, H., Camelid and shark single domain antibodies: structural features and therapeutic potential. Current Opinion in Structural Biology 2017, 45, 10-16.

13. Ehrenmann, J.; Schoppe, J.; Klenk, C.; Rappas, M.; Kummer, L.; Dore, A. S.; Pluckthun, A., Highresolution crystal structure of parathyroid hormone 1 receptor in complex with a peptide agonist. Nature Structural \& Molecular Biology 2018, 25 (12), 1086-+.

14. Zhao, L. H.; Ma, S. S.; Sutkeviciute, I.; Shen, D. D.; Zhou, X. E.; de Waal, P. W.; Li, C. Y.; Kang, Y. Y.; Clark, L. J.; Jean-Alphonse, F. G.; White, A. D.; Yang, D. H.; Dai, A. T.; Cai, X. Q.; Chen, J.; Li, C.; Jiang, Y.; Watanabe, T.; Gardella, T. J.; Melcher, K.; Wang, M. W.; Vilardaga, J. P.; Xu, H. E.; Zhang, Y., Structure and dynamics of the active human parathyroid hormone receptor-1. Science 2019, 364 (6436), $148-+$.

15. Guimaraes, C. P.; Witte, M. D.; Theile, C. S.; Bozkurt, G.; Kundrat, L.; Blom, A. E.; Ploegh, H. L., Site-specific C-terminal and internal loop labeling of proteins using sortase-mediated reactions. In Nat Protoc, England, 2013; Vol. 8, pp 1787-99.

16. Cheloha, R. W.; Gellman, S. H.; Vilardaga, J.-P.; Gardella, T. J., PTH receptor-1

signalling[mdash]mechanistic insights and therapeutic prospects. Nat Rev Endocrinol 2015, 11, 712-724.

17. Pioszak, A. A.; Xu, H. E., Molecular recognition of parathyroid hormone by its $\mathrm{G}$ protein-coupled receptor. Proceedings of the National Academy of Sciences of the United States of America 2008, 105 (13), 5034-5039.

18. Lee, C. W.; Gardella, T. J.; Abousamra, A. B.; Nussbaum, S. R.; Segre, G. V.; Potts, J. T.; Kronenberg, H. M.; Juppner, H., ROLE OF THE EXTRACELLULAR REGIONS OF THE PARATHYROIDHORMONE (PTH) PTH-RELATED PEPTIDE RECEPTOR IN HORMONE-BINDING. Endocrinology 1994, 135 (4), 1488-1495. 
19. Mahon, M. J., pHluorin2: an enhanced, ratiometric, pH-sensitive green florescent protein. Adv Biosci Biotechnol 2011, 2 (3), 132-137.

20. Carter, P. H.; Dean, T.; Bhayana, B.; Khatri, A.; Rajur, R.; Gardella, T. J., Actions of the Small Molecule Ligands SW106 and AH-3960 on the Type-1 Parathyroid Hormone Receptor. Molecular Endocrinology 2015, 29 (2), 307-321.

21. Ling, J.; Cheloha, R. W.; McCaul, N.; Sun, Z.-Y. J.; Wagner, G.; Ploegh, H. L. A nanobody that recognizes a 14-residue peptide epitope in the E2 ubiquitin-conjugating enzyme UBC6e modulates its activity bioRxiv 2019, DOI 10.1101/700609.

22. Kirchhofer, A.; Helma, J.; Schmidthals, K.; Frauer, C.; Cui, S.; Karcher, A.; Pellis, M.; Muyldermans, S.; Casas-Delucchi, C. S.; Cardoso, M. C.; Leonhardt, H.; Hopfner, K. P.; Rothbauer, U., Modulation of protein properties in living cells using nanobodies. Nature Structural \& Molecular Biology 2010, 17 (1), 133-U162.

23. Adams, H.; Saunders, M. J. S.; De Haard, J. J. W. AMINO ACID SEQUENCES DIRECTED AGAINST GPCRS AND POLYPEPTIDES COMPRISING THE SAME FOR THE TREATMENT OF GPCR-RELATED DISEASES AND DISORDERS. 2010. Patent number: US 2010/0062004 A1

24. Rashidian, M.; Keliher, E. J.; Bilate, A. M.; Duarte, J. N.; Wojtkiewicz, G. R.; Jacobsen, J. T.; Cragnolini, J.; Swee, L. K.; Victora, G. D.; Weissleder, R.; Ploegh, H. L., Noninvasive imaging of immune responses. Proceedings of the National Academy of Sciences of the United States of America 2015, 112 (19), 6146-6151.

25. Duarte, J. N.; Cragnolini, J. J.; Swee, L. K.; Bilate, A. M.; Bader, J.; Ingram, J. R.; Rashidfarrokhi, A.; Fang, T.; Schiepers, A.; Hanke, L.; Ploegh, H. L., Generation of Immunity against Pathogens via Single-Domain Antibody-Antigen Constructs. Journal of Immunology 2016, 197 (12), 4838-4847.

26. Okazaki, M.; Ferrandon, S.; Vilardaga, J. P.; Bouxsein, M. L.; Potts, J. T.; Gardella, T. J., Prolonged signaling at the parathyroid hormone receptor by peptide ligands targeted to a specific receptor conformation. Proceedings of the National Academy of Sciences of the United States of America 2008, 105 (43), 16525-16530.

27. Cheloha, R. W.; Maeda, A.; Dean, T.; Gardella, T. J.; Gellman, S. H., Backbone modification of a polypeptide drug alters duration of action in vivo. Nature Biotechnology 2014, 32 (7), 653-655.

28. Liu, S.; Cheloha, R. W.; Watanabe, T.; Gardella, T. J.; Gellman, S. H., Receptor selectivity from minimal backbone modification of a polypeptide agonist. Proceedings of the National Academy of Sciences of the United States of America 2018, 115 (49), 12383-12388.

29. Ferrandon, S.; Feinstein, T. N.; Castro, M.; Wang, B.; Bouley, R.; Potts, J. T.; Gardella, T. J.; Vilardaga, J.-P., Sustained cyclic AMP production by parathyroid hormone receptor endocytosis. Nature Chemical Biology 2009, 5 (10), 734-742.

30. Binkowski, B. F.; Butler, B. L.; Stecha, P. F.; Eggers, C. T.; Otto, P.; Zimmerman, K.; Vidugiris, G.; Wood, M. G.; Encell, L. P.; Fan, F.; Wood, K. V., A Luminescent Biosensor with Increased Dynamic Range for Intracellular cAMP. Acs Chemical Biology 2011, 6 (11), 1193-1197.

31. Rabbani, S. A.; Yasuda, T.; Bennett, H. P. J.; Sung, W. L.; Zahab, D. M.; Tam, C. S.; Goltzman, D.; Hendy, G. N., RECOMBINANT HUMAN PARATHYROID-HORMONE SYNTHESIZED IN ESCHERICHIA-COLI - PURIFICATION AND CHARACTERIZATION. Journal of Biological Chemistry 1988, 263 (3), 1307-1313.

32. Cheloha, R. W.; Chen, B. M.; Kumar, N. N.; Watanabe, T.; Thorne, R. G.; Li, L. J.; Gardella, T. J.; Gellman, S. H., Development of Potent, Protease-Resistant Agonists of the Parathyroid Hormone Receptor with Broad beta Residue Distribution. Journal of Medicinal Chemistry 2017, 60 (21), 88168833.

33. Neri, D., Antibody-Cytokine Fusions: Versatile Products for the Modulation of Anticancer Immunity. Cancer Immunology Research 2019, 7 (3), 348-354. 
34. Tzeng, A.; Kwan, B. H.; Opel, C. F.; Navaratna, T.; Wittrup, K. D., Antigen specificity can be irrelevant to immunocytokine efficacy and biodistribution. Proceedings of the National Academy of Sciences of the United States of America 2015, 112 (11), 3320-3325.

35. Garcin, G.; Paul, F.; Staufenbiel, M.; Bordat, Y.; Van der Heyden, J.; Wilmes, S.; Cartron, G.; Apparailly, F.; De Koker, S.; Piehler, J.; Tavernier, J.; Uze, G., High efficiency cell-specific targeting of cytokine activity. Nature Communications 2014, 5.

36. Pogue, S. L.; Taura, T.; Bi, M. Y.; Yun, Y.; Sho, A.; Mikesell, G.; Behrens, C.; Sokolovsky, M.; Hallak, H.; Rosenstock, M.; Sanchez, E.; Chen, H. M.; Berenson, J.; Doyle, A.; Nock, S.; Wilson, D. S., Targeting Attenuated Interferon-alpha to Myeloma Cells with a CD38 Antibody Induces Potent Tumor Regression with Reduced Off-Target Activity. Plos One 2016, 11 (9).

37. Farrants, H.; Gutzeit, V. A.; Acosta-Ruiz, A.; Trauner, D.; Johnsson, K.; Levitz, J.; Broichhagen, J., SNAP-Tagged Nanobodies Enable Reversible Optical Control of a G Protein-Coupled Receptor via a Remotely Tethered Photoswitchable Ligand. Acs Chemical Biology 2018, 13 (9), 2682-2688.

38. Chodorge, M.; Celeste, A. J.; Grimsby, J.; Konkar, A.; Davidsson, P.; Fairman, D.; Jenkinson, L.; Naylor, J.; White, N.; Seaman, J. C.; Dickson, K.; Kemp, B.; Spooner, J.; Rossy, E.; Hornigold, D. C.; Trevaskis, J. L.; Bond, N. J.; London, T. B.; Buchanan, A.; Vaughan, T.; Rondinone, C. M.; Osbourn, J. K., Engineering of a GLP-1 analogue peptide/anti-PCSK9 antibody fusion for type 2 diabetes treatment. Scientific Reports 2018, 8.

39. Shimizu, M.; Carter, P. H.; Gardella, T. J., Autoactivation of type-1 parathyroid hormone receptors containing a tethered ligand. Journal of Biological Chemistry 2000, 275 (26), 19456-19460.

40. Devigny, C.; Perez-Balderas, F.; Hoogeland, B.; Cuboni, S.; Wachtel, R.; Mauch, C. P.; Webb, K. J.; Deussing, J. M.; Hausch, F., Biomimetic Screening of Class-B G Protein-Coupled Receptors. Journal of the American Chemical Society 2011, 133 (23), 8927-8933.

41. Urban, D. J.; Roth, B. L., DREADDs (Designer Receptors Exclusively Activated by Designer Drugs): Chemogenetic Tools with Therapeutic Utility. Annual Review of Pharmacology and Toxicology, Vol 55 2015, 55, 399-417.

42. Armbruster, B. N.; Li, X.; Pausch, M. H.; Herlitze, S.; Roth, B. L., Evolving the lock to fit the key to create a family of $\mathrm{G}$ protein-coupled receptors potently activated by an inert ligand. Proceedings of the National Academy of Sciences of the United States of America 2007, 104 (12), 5163-5168.

43. Guettier, J. M.; Gautam, D.; Scarselli, M.; de Azua, I. R.; Li, J. H.; Rosemond, E.; Ma, X. C.; Gonzalez, F. J.; Armbruster, B. N.; Lu, H. Y.; Roth, B. L.; Wess, J., A chemical-genetic approach to study $G$ protein regulation of beta cell function in vivo. Proceedings of the National Academy of Sciences of the United States of America 2009, 106 (45), 19197-19202.

44. Sockolosky, J. T.; Trotta, E.; Parisi, G.; Picton, L.; Su, L. L.; Le, A. C.; Chhabra, A.; Silveria, S. L.; George, B. M.; King, I. C.; Tiffany, M. R.; Jude, K.; Sibener, L. V.; Baker, D.; Shizuru, J. A.; Ribas, A.; Bluestone, J. A.; Garcia, K. C., Selective targeting of engineered T cells using orthogonal IL-2 cytokinereceptor complexes. Science 2018, 359 (6379), 1037-+.

45. Alvarez-Curto, E.; Milligan, G., Defining the Functional Equivalence of Wild-Type and Chemically Engineered G Protein-Coupled Receptors. Designer Receptors Exclusively Activated by Designer Drugs 2015, 108, 1-28.

46. Maeda, A.; Okazaki, M.; Baron, D. M.; Dean, T.; Khatri, A.; Mahon, M.; Segawa, H.; AbouSamra, A. B.; Jueppner, H.; Bloch, K. D.; Potts, J. T., Jr.; Gardella, T. J., Critical role of parathyroid hormone (PTH) receptor-1 phosphorylation in regulating acute responses to PTH. Proceedings of the National Academy of Sciences of the United States of America 2013, 110 (15), 5864-5869.

47. Herenbrink, C. K.; Sykes, D. A.; Donthamsetti, P.; Canals, M.; Coudrat, T.; Shonberg, J.; Scammells, P. J.; Capuano, B.; Sexton, P. M.; Charlton, S. J.; Javitch, J. A.; Christopoulos, A.; Lane, J. R., The role of kinetic context in apparent biased agonism at GPCRs. Nature Communications 2016, 7. 

SUPPORTING INFORMATION

Improved GPCR ligands based on genetically impossible nanobody-peptide fusions.

\begin{tabular}{lll} 
Peptide & {$[\mathrm{M}+\mathrm{H}]_{\text {calc }}$} & {$[\mathrm{M}+\mathrm{H}]_{\text {obs }}$} \\
\hline PTH(1-9) & 1127.6 & 1127.1 \\
\hline PTH(1-10) & 1255.6 & 1255.1 \\
\hline PTH(1-11) & 1411.7 & 1411.2 \\
\hline PTH(1-14) & 1796.9 & 1796.3 \\
\hline PTH(1-34) & 4218.2 & 4217.5 \\
\hline PTH(1-9)-dbco & 1554.8 & 1554.2 \\
\hline PTH(1-10)-dbco & 1682.8 & 1682.2 \\
\hline PTH(1-11)-dbco & 1838.9 & 1839 \\
\hline PTH(1-14)-dbco & 2224.1 & 2223.5 \\
\hline PTH(1-34)-dbco & 4645.4 & 4644.6 \\
\hline PTH(1-11)-PEG3-dbco & 2042 & 2041.4 \\
\hline PTH(1-34)-PEG3-dbco & 4848.5 & 4847.7 \\
\hline G 3 -PTH(1-14) & 1865 & 1864.2
\end{tabular}

Supporting Figure 1. Confirmation of peptide identity using mass spectrometry. Peptides were analyzed by $\mathrm{LC} / \mathrm{MS}$ as described in methods. Calculated masses $\left([\mathrm{M}+\mathrm{H}]_{\text {calc }}\right)$ refers to the monoisotopic mass of a singly protonated species. The masses recorded using mass spectrometry are labeled as $[\mathrm{M}+\mathrm{H}]_{\text {obs. }}$. 


\begin{tabular}{|c|c|c|}
\hline Conugate & $\mathrm{MW}_{\text {calc }}$ & $\mathrm{MW}_{\text {obs }}$ \\
\hline VHH ${ }_{\text {GFP-G3-Lys(biotin)AhxLys(azide) }}$ & $\mathrm{n} / \mathrm{a}$ & 14080 \\
\hline $\mathrm{VHH}_{\mathrm{GFP}}-\mathrm{PTH}(1-9)$ & 15635 & 15635 \\
\hline VHH & 15763 & 15765 \\
\hline $\mathrm{VHH}_{\mathrm{GFP}}-\mathrm{PTH}(1-11)$ & 15919 & 15920 \\
\hline $\mathrm{VHH}_{\mathrm{GFP}}-\mathrm{PTH}(1-14)$ & 16304 & 16305 \\
\hline VHH ${ }_{\text {GFP-G3-PTH(1-14) }}$ & 15135 & 15135 \\
\hline $\mathrm{VHH}_{\mathrm{GFP}}-\mathrm{PTH}(1-34)-\mathrm{PEG}$ & 18929 & 18930 \\
\hline $\mathrm{VHH}_{6 \mathrm{E}}-\mathrm{G} 3-\mathrm{Lys}($ biotin)AhxLys(azide) & $\mathrm{n} / \mathrm{a}$ & 13325 \\
\hline $\mathrm{VHH}_{6 \mathrm{E}}-\mathrm{PTH}(1-9)$ & 14880 & 14895 \\
\hline $\mathrm{VHH}_{6 \mathrm{E}}-\mathrm{PTH}(1-10)$ & 15008 & 15010 \\
\hline VHH ${ }_{6 E}-P T H(1-11)$ & 15164 & 15165 \\
\hline $\mathrm{VHH}_{6 \mathrm{E}}-\mathrm{PTH}(1-11)-\mathrm{PEG}$ & 15367 & 15375 \\
\hline $\mathrm{VHH}_{6 \mathrm{E}}-\mathrm{PTH}(1-14)$ & 15549 & 15550 \\
\hline $\mathrm{VHH}_{6 \mathrm{E}}-\mathrm{PTH}(1-34)-\mathrm{PEG}$ & 18174 & 18175 \\
\hline VHH 6 -G3-PTH(1-14) & 14380 & 14380 \\
\hline VHH ${ }_{\text {PTHR }}-\mathrm{PTH}(1-9)$ & 16505 & 16505 \\
\hline VHH ${ }_{\text {PTHR }}-\mathrm{PTH}(1-10)$ & 16633 & 16635 \\
\hline VHH ${ }_{\text {PTHR }}-\mathrm{PTH}(1-11)$ & 16789 & 16790 \\
\hline VHH & 17174 & 17175 \\
\hline VHH ${ }_{\text {PTHR-G3-Lys(biotin)AhxLys(azide) }}$ & $\mathrm{n} / \mathrm{a}$ & 14950 \\
\hline VHHPTHR-G3-PTH(1-14) & 16005 & 16005 \\
\hline
\end{tabular}

Supporting Figure 2. Confirmation of VHH-peptide conjugate identity using mass spectrometry. VHHpeptide conjugates were analyzed by LC/MS as described in methods. Deconvolution calculations were used to provide the observed values. $\mathrm{MW}_{\text {calc }}$ refers to the calculated average molecular weight and $\mathrm{MW}_{\text {obs }}$ refers to the molecular weight recorded by mass spectrometry. 

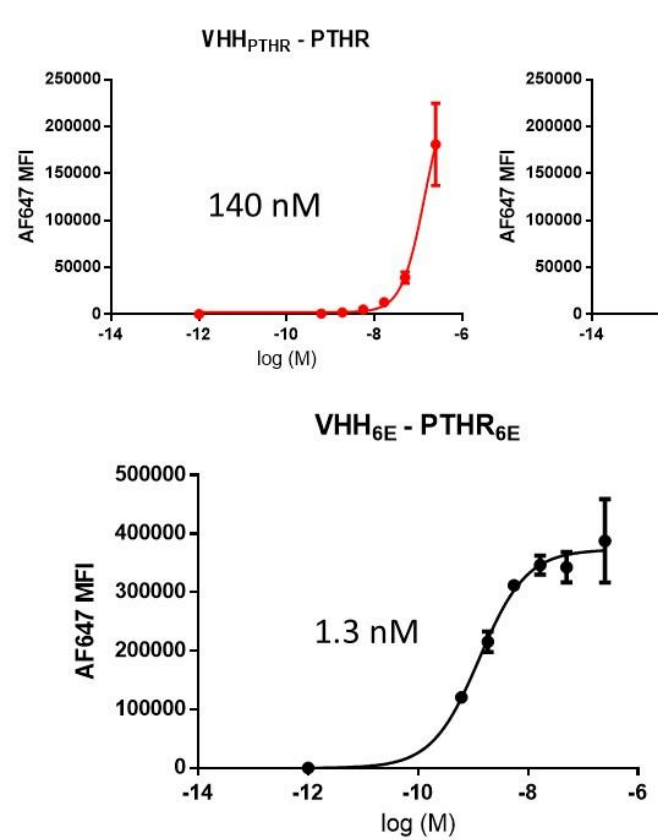
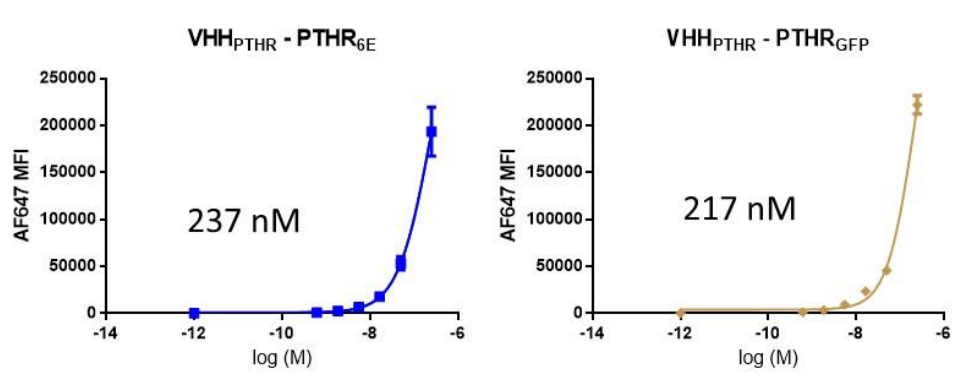

VHH $_{\text {GFP-PTHRdeINT-YFP }}$

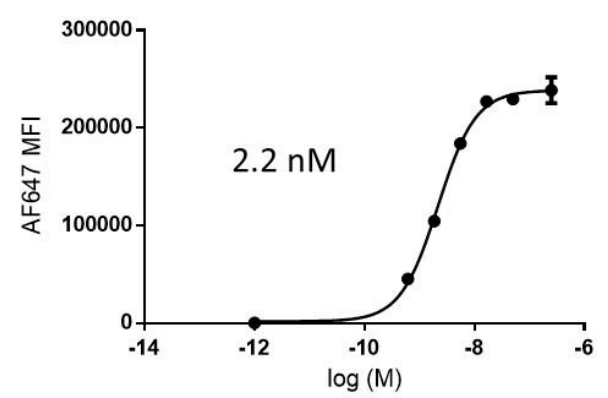

Supporting Figure 3. Assessment of VHH binding to PTHR1 variants expressed on HEK293 cell lines by flow cytometry. Cells dislodged from tissue culture plates using trypsinization were incubated with varied concentrations of VHHs sortagged with AlexaFluor647 on ice for $1 \mathrm{~h}$. Cells were centrifuged, washed, and analyzed by flow cytometry via gating of intact cells based on forward scatter/side scatter profiles. Data points represent median fluorescent intensity values (mean \pm SD). Connecting curves are the result of fitting a sigmoidal dose-response model to the data points. The plateau for maximum labeling using $\mathrm{VHH}_{\text {PTHR }}$ was estimated based on maximal labeling with other VHHs.
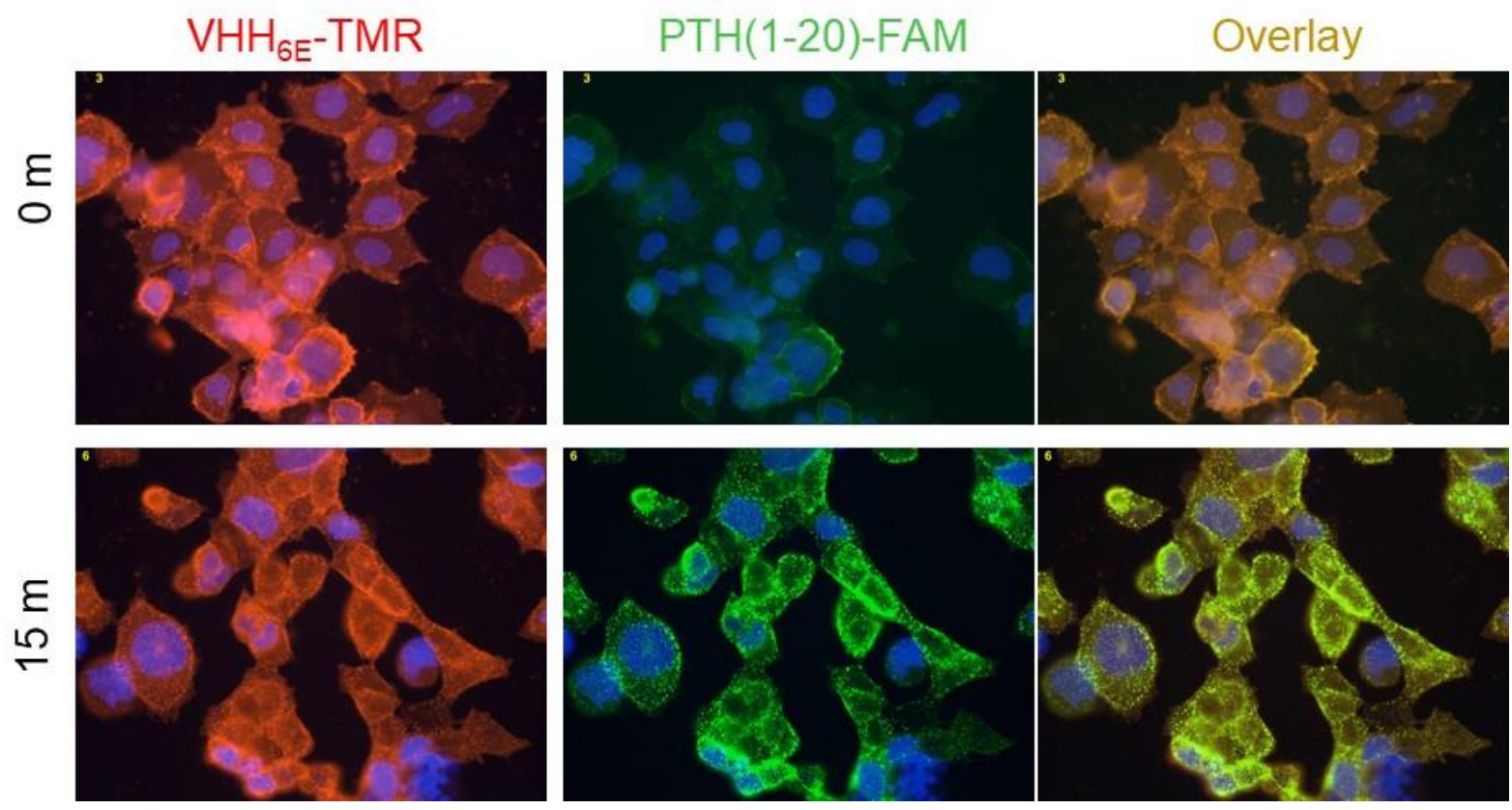

Supporting Figure 4: Assessment of $\mathrm{VHH}_{6 \mathrm{E}}$ and PTH(1-20) binding to PTHR1 ${ }_{6 \mathrm{E}}$ using microscopy. Adherent HEK293 cells expressing human PTHR1 were stained on ice with 300 nM VHH 6 -TMR and 30 
nM PTH(1-20)-FAM for 30 minutes. Following staining cells were washed and treated with fixative in preparation for image acquisition either immediately after staining $(0 \mathrm{~m})$ or following a 15 minute incubation in medium at room temperature $(15 \mathrm{~m})$.

a)

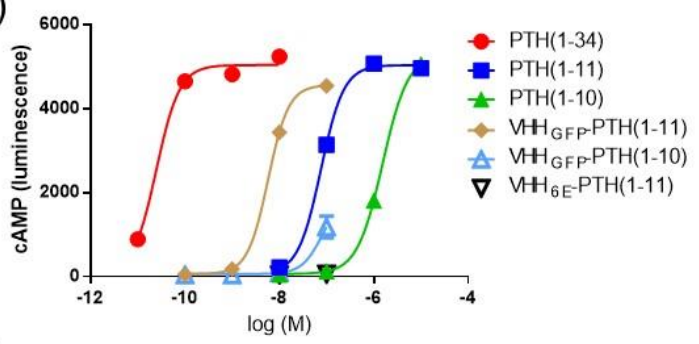

c)

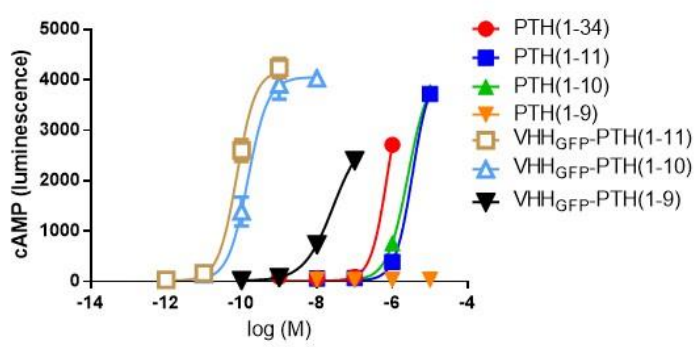

e)

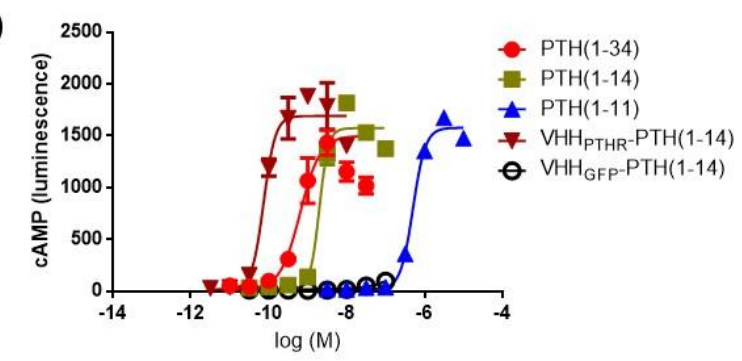

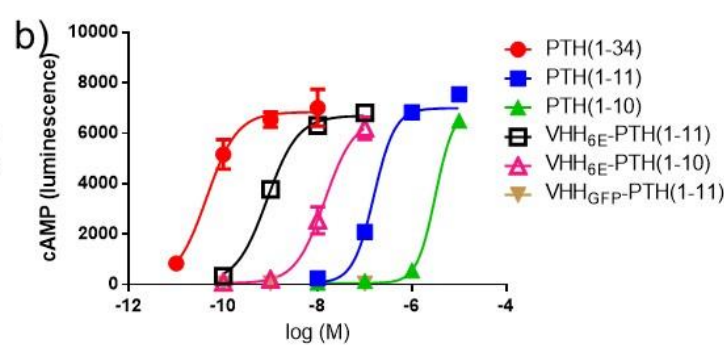

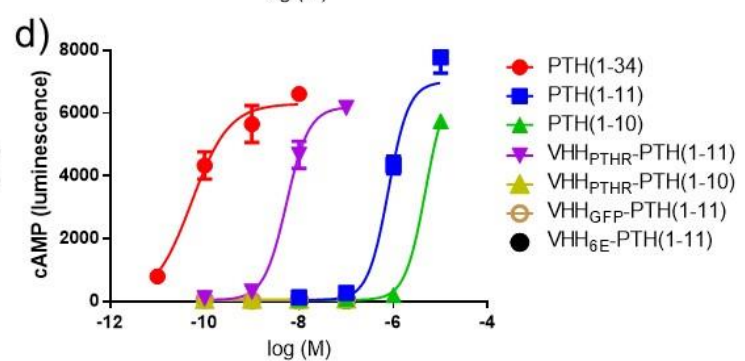

Supporting Figure 5. Representative dose-response curves for CAMP induction in HEK293 cell lines. HEK293 cell lines were activated with peptides or conjugates as described in methods. Data points represent mean $\pm S D$ and connecting lines result from the fit of a four-parameter sigmoidal dose-

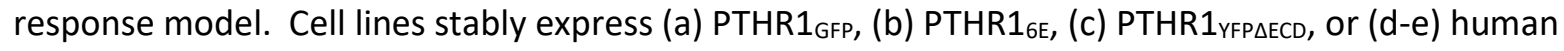
PTHR1. 
a) Nanobody-ligand C-to-N fusion $\mathrm{X}$

b)

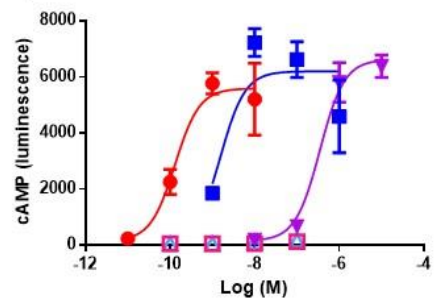

Nanobody-ligand C-to-C fusion

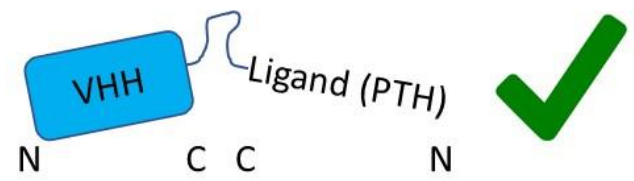

c)

\begin{tabular}{lrrrr} 
Peptide/conjugate & \multicolumn{2}{c}{$\mathrm{EC}_{50}, \mathrm{nM}( \pm \mathrm{SD})$} & $\mathrm{n}$ \\
\hline $\mathrm{PTH}(1-34)$ & 0.38 & \pm & 0.23 & 4 \\
$\mathrm{PTH}(1-14)$ & 2.8 & \pm & 1.5 & 4 \\
$\mathrm{G}_{3}-\mathrm{PTH}(1-14)$ & $208 \quad \pm 135$ & 4 \\
$\mathrm{VHH}_{\mathrm{PTHR}}-\mathrm{G}_{3}-\mathrm{PTH}(1-14)$ & No activity at $100 \mathrm{nM}$ & 3 \\
$\mathrm{VHH}_{6 \mathrm{E}}-\mathrm{G}_{3}-\mathrm{PTH}(1-14)$ & No activity at $100 \mathrm{nM}$ & 3
\end{tabular}

Supporting Figure 6. Modification of the $\mathrm{N}$-terminus of PTH degrades activity. (a) Schematic comparison of the topology of the two types of conjugates tested. (b) Representative dose-response curves for activation of human PTHR1 by indicated peptides or conjugates run as described in methods. Data points indicate mean \pm SD and connecting lines result from the fit of a four-parameter sigmoidal dose-response model. (c) Tabulation of cAMP induction potencies. 

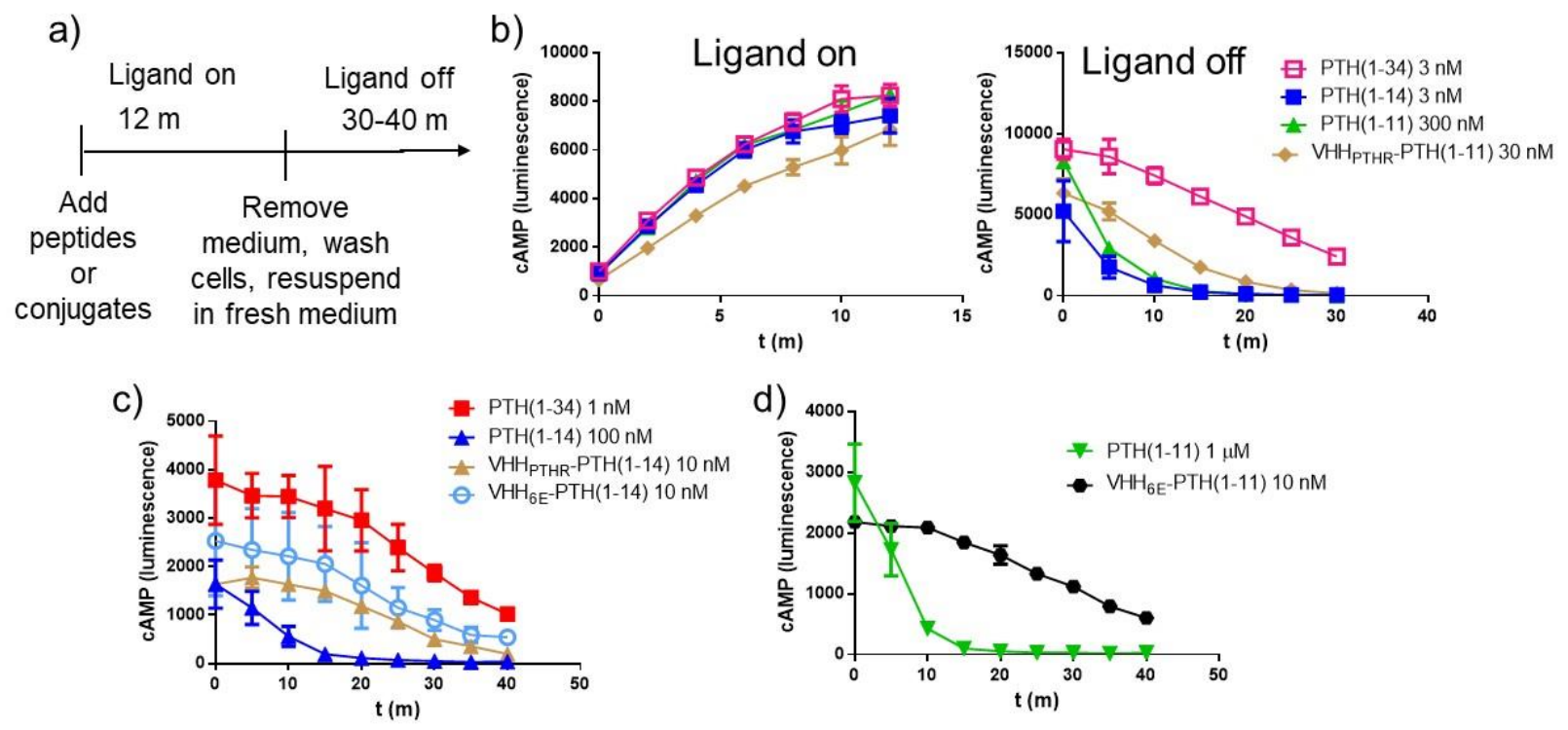

e)
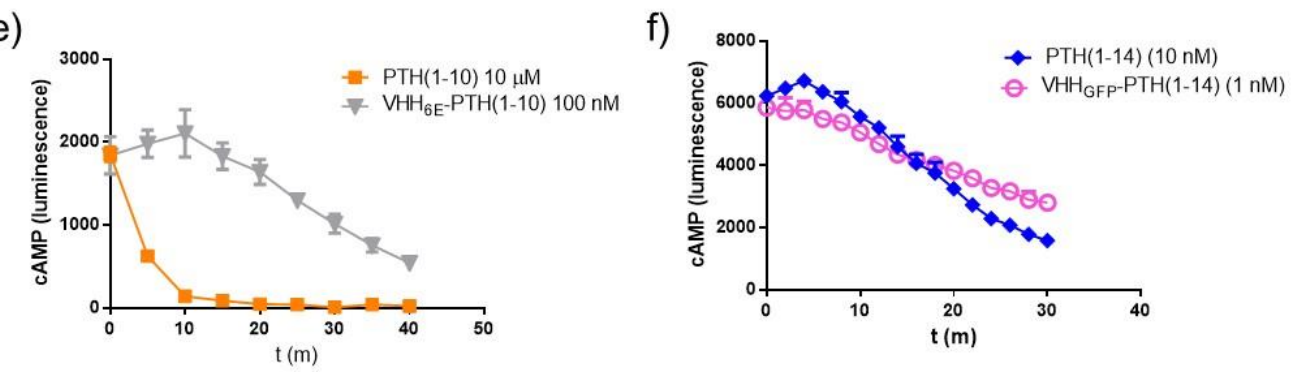

g)
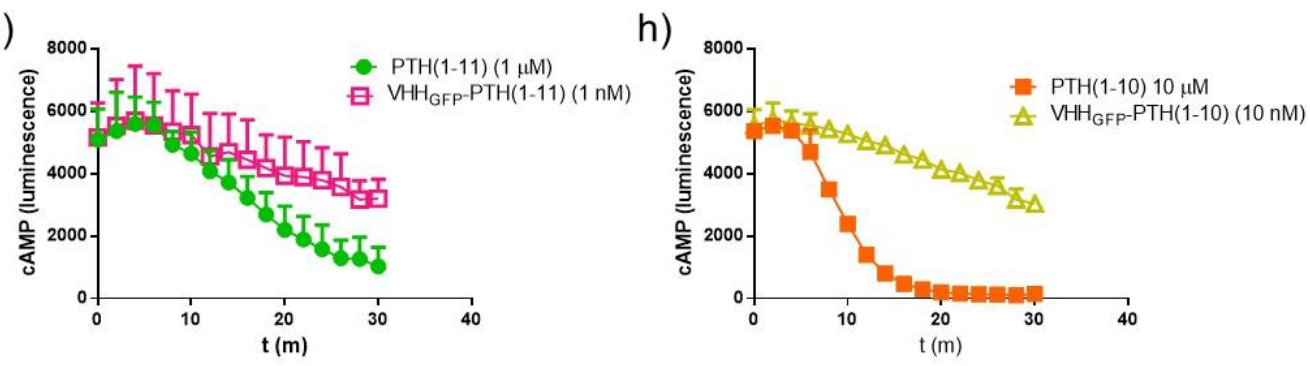

Supporting Figure 7. VHH anchoring of PTH fragments prolongs CAMP signaling. Cells were treated with peptides or conjugates at concentrations listed in the legend for each figure to stimulate CAMP responses as described in methods. (a) Scheme describing workflow for cAMP kinetics experiments. CAMP responses were recorded every two minutes following addition of peptide and after washout of free peptide. The time needed for medium removal, washing of cells, and resuspension in fresh medium spans approximately 2 minutes. (b) Representative plots of the kinetics of cAMP-induced signal production (left) and signal cessation after removal of medium containing from ligand (right) in hPTHR1 expressing HEK293 cells. Ligands were used at the minimal concentration that stimulated near maximal cAMP responses to minimize effects from non-specific adherence. Data points indicate mean \pm SD from three replicates. Lines connect data points and only serve to guide the eye. The ligand on phase was omitted from panels $\mathrm{c}-\mathrm{h}$ but each ligand tested induced a similar cAMP response prior to washout (data not shown). (c-h) Ligand off phase following stimulation of cells expressing (c-e) PTHR1 $1_{6 E}$ or (f-h) PTHR1 YFPAECD. Data from individual cell lines are separated into separate panels for clarity. 

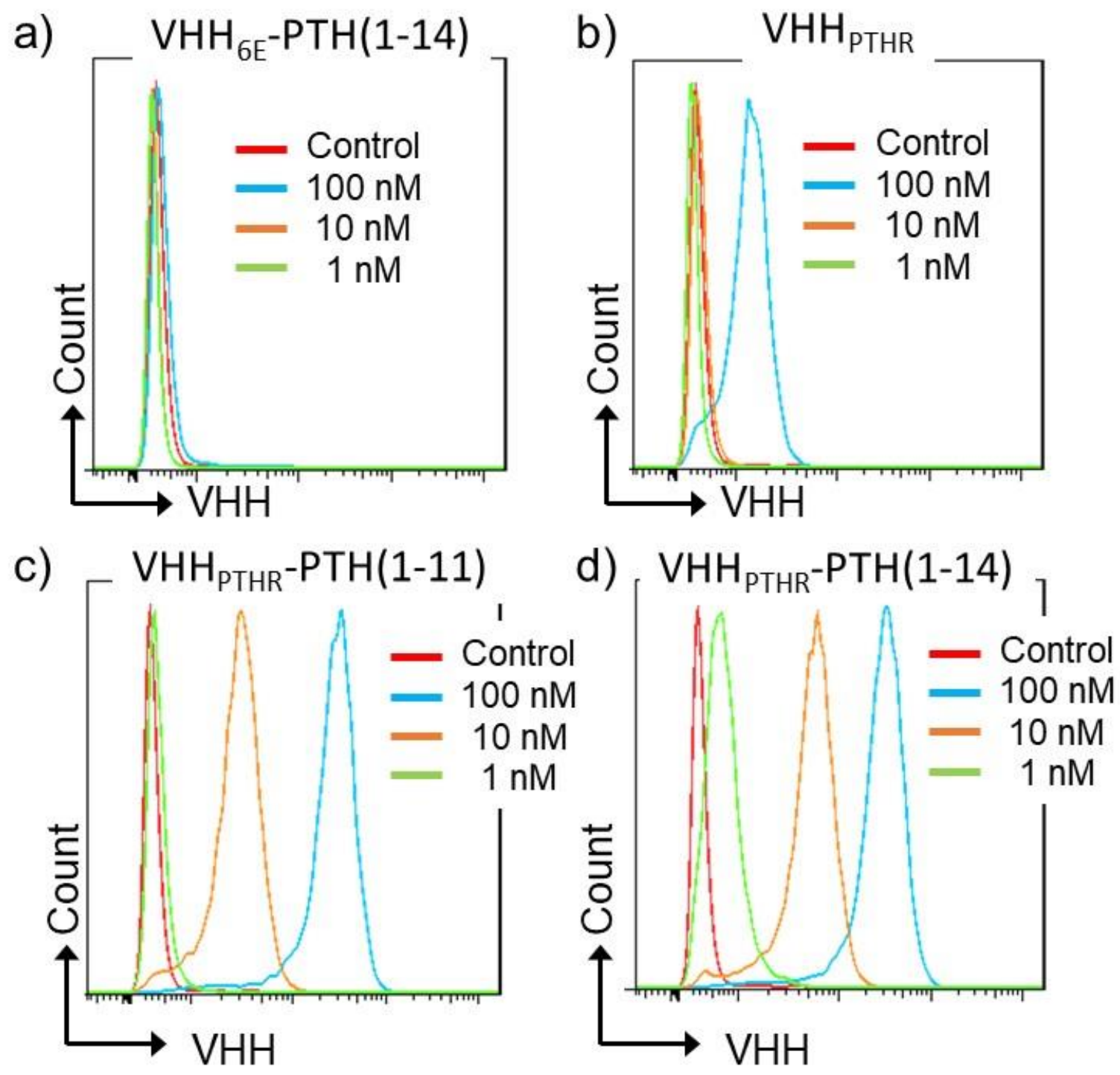

Supporting Figure 8. Variation in binding caused by conjugation of receptor-binding or irrelevant VHHs. HEK293 cells expressing PTHR1 were stained with conjugates indicated in panels a-d at concentrations listed in legends and prepared for analysis by flow cytometry as described in methods. The control staining condition for each panel was staining with $\mathrm{VHH}_{6 \mathrm{E}}$-biotin-azide used at a

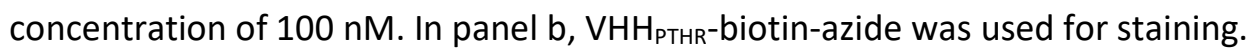


a)
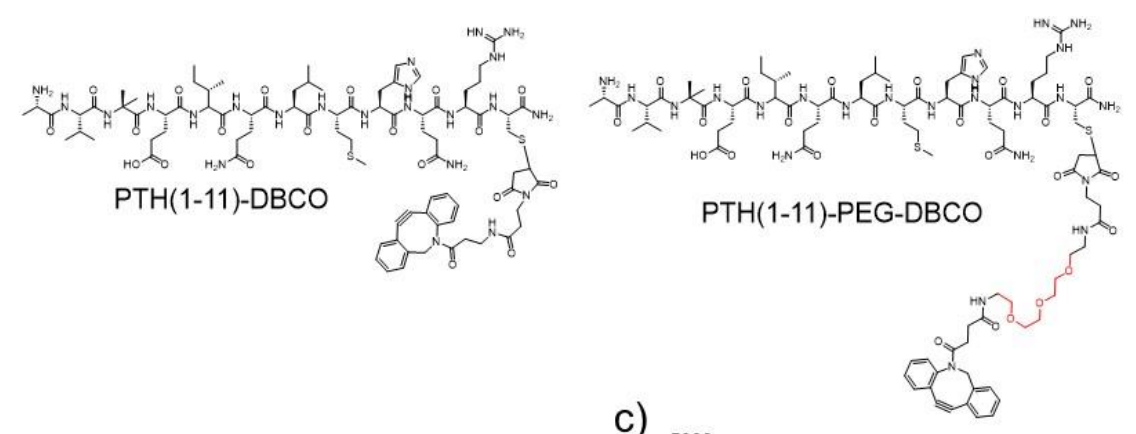

b)
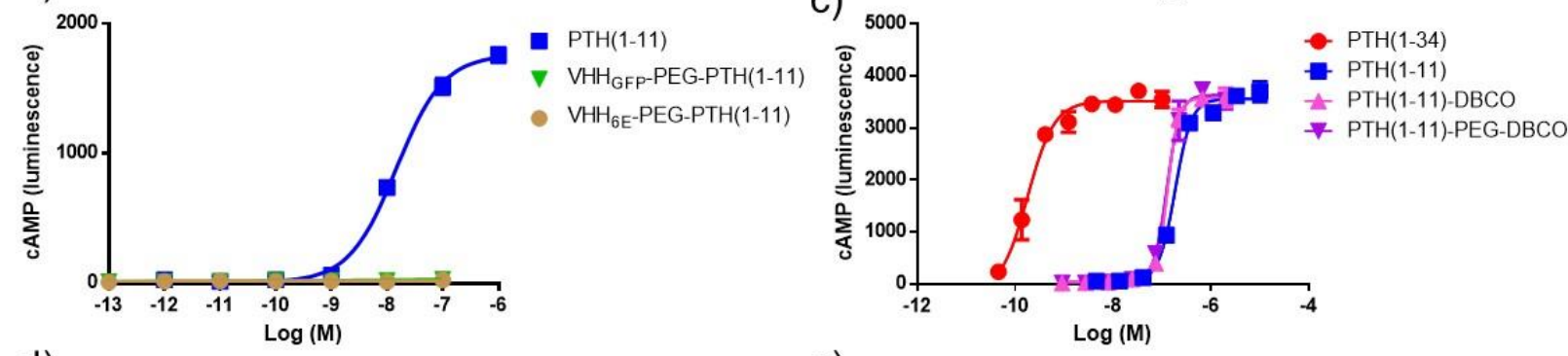

d)

e)

\begin{tabular}{lrrrr} 
Peptide/conjugate & \multicolumn{2}{c}{$\mathrm{EC}_{50}, \mathrm{nM}( \pm \mathrm{SD})$} & $\mathrm{n}$ \\
\hline PTH(1-34) & 0.67 & \pm & 0.64 & 6 \\
PTH(1-11) & 336 & \pm & 208 & 7 \\
PTH(1-11)-DBCO & 65 & \pm & 48 & 4 \\
PTH(1-11)-PEG-DBCO & 145 & \pm & 17 & 3 \\
VHH $_{\text {GFP-PEG-PTH(1-11) }}$ & No activity at $100 \mathrm{nM}$ & 3 \\
VHH $_{6 E}-$ PEG-PTH(1-11) & \multicolumn{2}{l}{ No activity at $100 \mathrm{nM}$} & 2
\end{tabular}

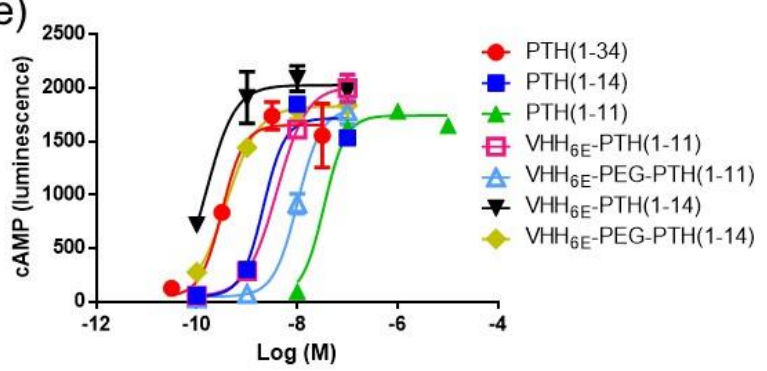

f) \begin{tabular}{lrlll} 
& \multicolumn{2}{c}{$\mathrm{EC}_{50}, \mathrm{nM}( \pm \mathrm{SD})$} & $\mathrm{n}$ \\
\hline $\mathrm{PTH}(1-34)$ & 1.3 & \pm & 0.98 & 3 \\
PTH(1-14) & 3.4 & \pm & 2 & 3 \\
PTH(1-11) & 94 & \pm & 74 & 3 \\
$\mathrm{VHH}_{6 E}-\mathrm{PTH}(1-14)$ & 0.43 & \pm & 0.24 & 3 \\
$\mathrm{VHH}_{6 E}-\mathrm{PEG}-\mathrm{PTH}(1-14)$ & 0.81 & \pm & 0.36 & 3 \\
$\mathrm{VHH}_{6 E}-\mathrm{PTH}(1-11)$ & 6.9 & \pm & 2.6 & 3 \\
$\mathrm{VHH}_{6 E}-\mathrm{PEG}-\mathrm{PTH}(1-11)$ & 21 & \pm & 9.8 & 3
\end{tabular}

Supporting Figure 9. Impact of DBCO conjugation and PEG linker insertion on peptide and conjugate bioactivity. Peptides and VHH-peptide conjugates were assessed for cAMP induction in HEK293 cell lines as described in methods. Data points represent mean $\pm S D$ and connecting lines result from the fit of a four-parameter sigmoidal dose-response model. (a) Structure of PTH(1-11) fused to either DBCO or $\mathrm{PEG}_{3}-\mathrm{DBCO}$ to illustrate connectivity. Atoms corresponding to the PEG linker are highlighted in red. (b-c) Representative dose-response curves for stimulation of human PTHR1. (b) Insertion of a PEG linker does $^{2}$ not enable activation of receptors not bound by VHHs by VHH-PTH(1-11) conjugates. (c) Attachment of DBCO or PEG-DBCO to PTH(1-11) does not substantially alter receptor activation properties. (d) Tabulation of experimental results for activation of hPTHR1 by PTH and conjugates. These data are distinct from those presented in Table 1. (e) Representative dose-response curve for stimulation of PTHR1 $1_{6 E}$ by DBCO and PEG-DBCO conjugates of PTH fragments. Insertion of a PEG 3 linker does not substantially alter receptor activation properties. (f) Tabulation of experimental results for activation of PTHR1-6E by PTH and conjugates. These data are distinct from those presented in Table 1. 
a)

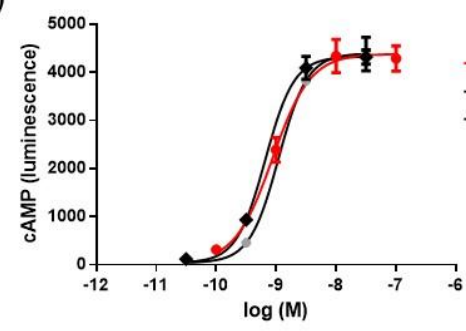

Peptide/conjugate $\mathrm{PTH}(1-34)$

VHH $\mathrm{H}_{\text {GFP }}$-PEG-PTH(1-34)

$\mathrm{VHH}_{6 \mathrm{E}}-\mathrm{PEG}-\mathrm{PTH}(1-34)$

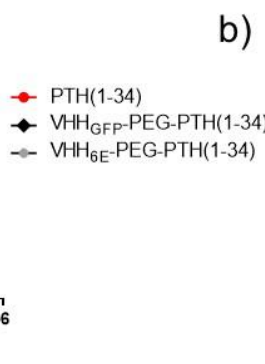

b)

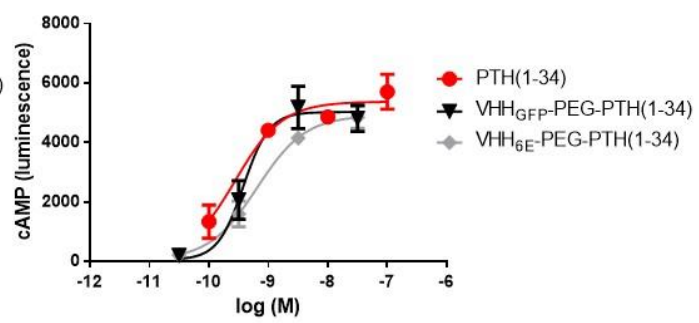

\begin{tabular}{lllll} 
Peptide/conjugate & \multicolumn{2}{c}{$\mathrm{EC}_{50}, \mathrm{nM}( \pm \mathrm{SD})$} & $\mathrm{n}$ \\
\hline $\mathrm{PTH}(1-34)$ & 1.05 & \pm & 1.26 & 4 \\
VHH $_{\text {GFP-PEG-PTH(1-34 }}$ & 0.90 & \pm & 0.78 & 3 \\
VHH $_{6 E}$-PEG-PTH(1-34) & 1.44 & \pm & 1.14 & 4
\end{tabular}

Supporting Figure 10. VHH conjugation does not affect signaling capacity of PTH(1-34). PTH(1-34)-Cys was conjugated to $\mathrm{VHH}$ with an intervening $\mathrm{PEG}_{3}$ linker as described in Figure 2 and Supporting Figure 8. The induction of cAMP responses was assessed in cell lines expressing (a) hPTHR1 or (b) PTHR1 $1_{6 E}$. Representative dose-response curves are shown in which data points indicate mean \pm SD and connecting lines result from the fit of a four-parameter sigmoidal dose-response model. Composite results are tabulated below the dose-response curves.

a)

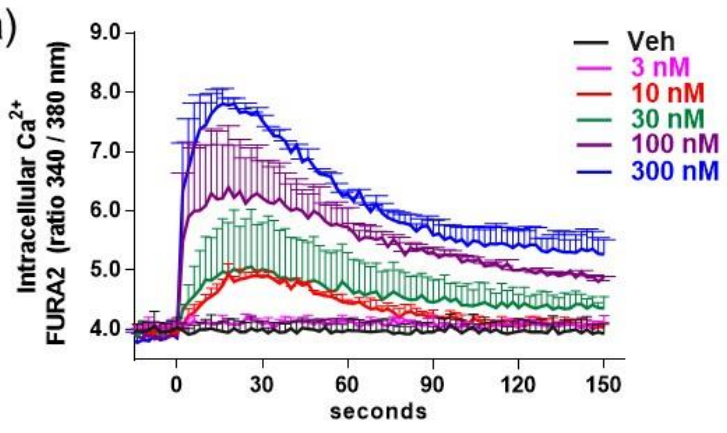

b)

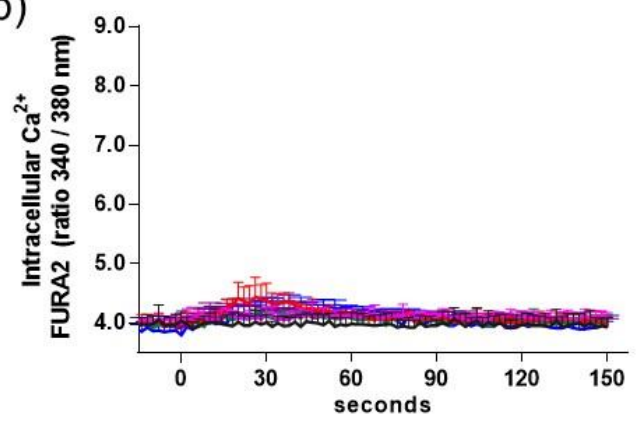

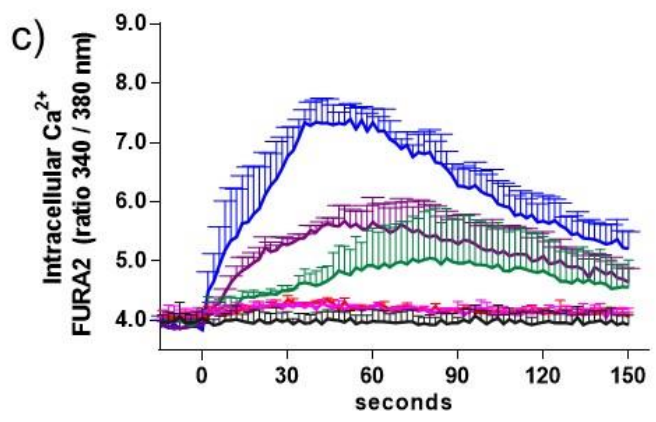

Supporting Figure 11. Measurement of cytoplasmic calcium mobilization by PTHR1 agonists. HEK293 cells were loaded with FURA2 then stimulated with (a) PTH(1-34), (b) VHH $\mathrm{PTHR}^{-} \mathrm{PTH}(1-11)$ or (c) $\mathrm{VHH}_{\mathrm{PTHR}^{-}}$ $\mathrm{PTH}(1-14)$ at time zero as described in the methods section. The colors used to represent each concentration are held consistent in each panel. Data points indicate mean \pm SEM from two independent measurements. 
a)

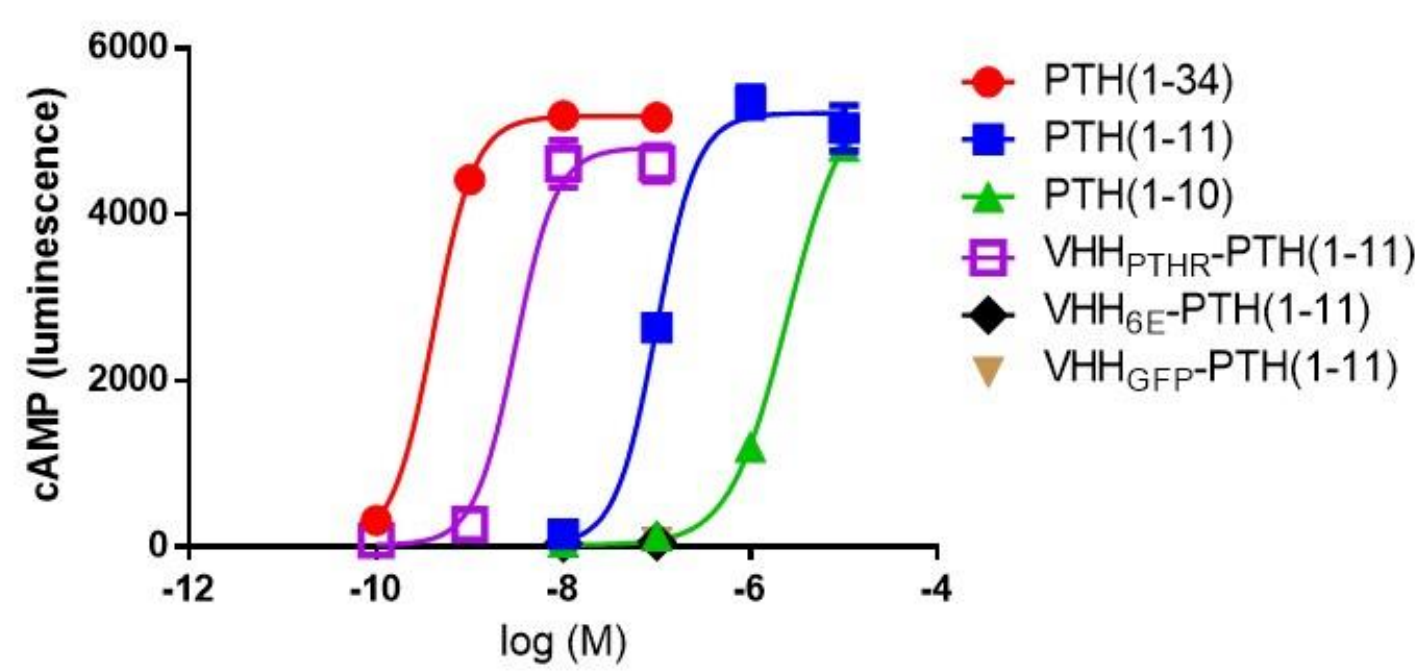

b)

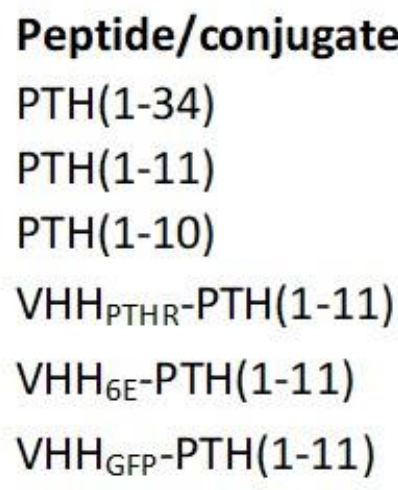

\begin{tabular}{rlll}
\multicolumn{3}{c}{$\mathrm{EC}_{\mathbf{5 0}}(\mathrm{nM} \pm \mathrm{SD})$} & $\boldsymbol{n}$ \\
0.28 & \pm & 0.12 & 3 \\
120.3 & \pm & 90.3 & 3 \\
2466 & \pm & 23 & 3 \\
3.2 & \pm & 0.9 & 3 \\
\multicolumn{3}{c}{$>100 \mathrm{nM}$} & 2 \\
& $>100 \mathrm{nM}$ & 2
\end{tabular}

Supporting Figure 12. VHH PTHR conjugation potentiates PTH fragment activation of rat PTHR1. HEK293 cells stably expressing rat PTHR1 were stimulated with peptide or conjugate as described in methods. (a) Representative dose-response curve for stimulation of rPTHR1 by peptides or VHH-PTH(1-11) conjugates. Data points indicate mean \pm SD and connecting lines result from the fit of a four-parameter sigmoidal dose-response model. (b) Tabulation of composite results from rPTHR1 cAMP stimulation assays. 


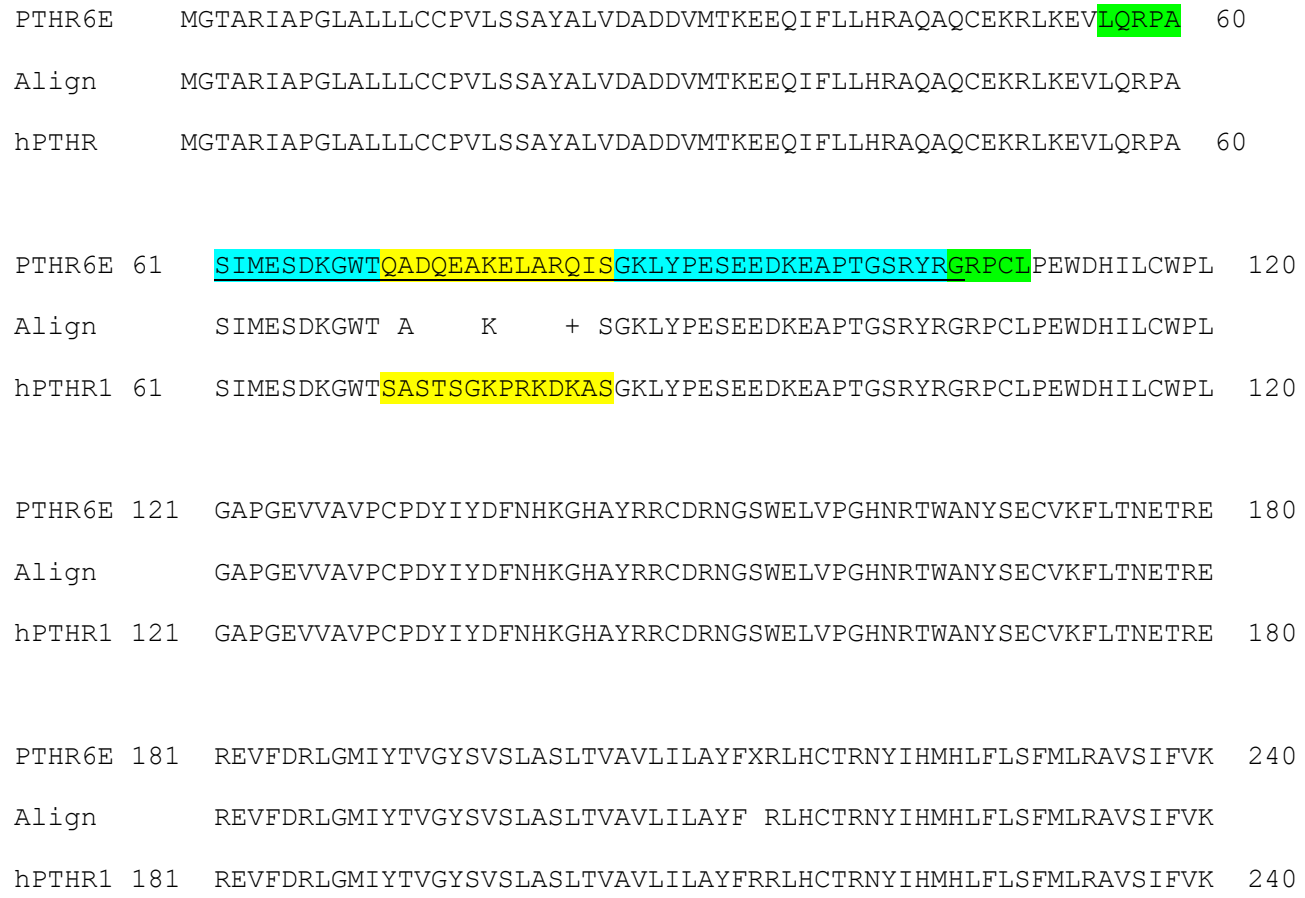

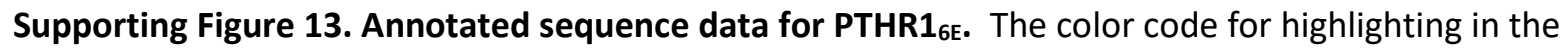
sequence is as follows: Green- sequences flanking exon 2 that are resolved in the crystal structure (PDB: 6FJ3); Cyan-resolved not in crystal structure; Yellow-site of 6E tag incorporation (not resolved in crystal structure. Sequence corresponding to Exon 2 is underlined. 
MGTARIAPGLALLLCCPVLSSAYALATMVSKGEELFTGVVPILVELDGDVNGHKFSVSGEGEGDATYGKLTLKLICTTGKLPVPWPTLVTTLGYGVQCFARYPDHMKQH DFFKSAMPEGYVQERTIFFKDDGNYKTRAEVKFEGDTLVNRIELKGIDFKEDGNILGHKLEYNYNSHNVYITADKQKNGIKANFKIRHNIEDGGVQLADHYQQNTPIGD GPVLLPDNHYLSYQSKLSKDPNEKRDHMVLLEFVTAAGITLGMDELYKGSGEVFDRLGMIYTVGYSVSLASLTVAVLILAYFRRLHCTRNYIHMHLFLSFMLRAVSIFVKD AVLYSGATLDEAERLTEEELRAIAQAPPPPATAAAGYAGCRVAVTFFLYFLATNYYWILVEGLYLHSLIFMAFFSEKKYLWGFTVFGWGLPAVFVAVWVSVRATLANTG CWDLSSGNKKWIIQVPILASIVLNFILFINIVRVLATKLRTNAGRCDTRQQYRKLLKSTLVLMPLFGVHYIVFMATPYTEVSGTLWQVQMHYEMLFNSFQGFFVAIIYCFC NGEVQAEIKKSWSRWTLALDFKRKARSGSSSYSYGPMVSHTSVTNVGPRVGLGLPLSPRLLPTATTNGHPQLPGHAKPGTPALETLETTPPAMAAPKDDGFLNGSCSG LDEEASGPERPPALLQEEWETVM

Supporting Figure 14. Sequence of PTHR1 YFPAECD. Sequence corresponding to hPTHR1 is highlighted in cyan. Sequence corresponding to YFP is highlighted in yellow. 


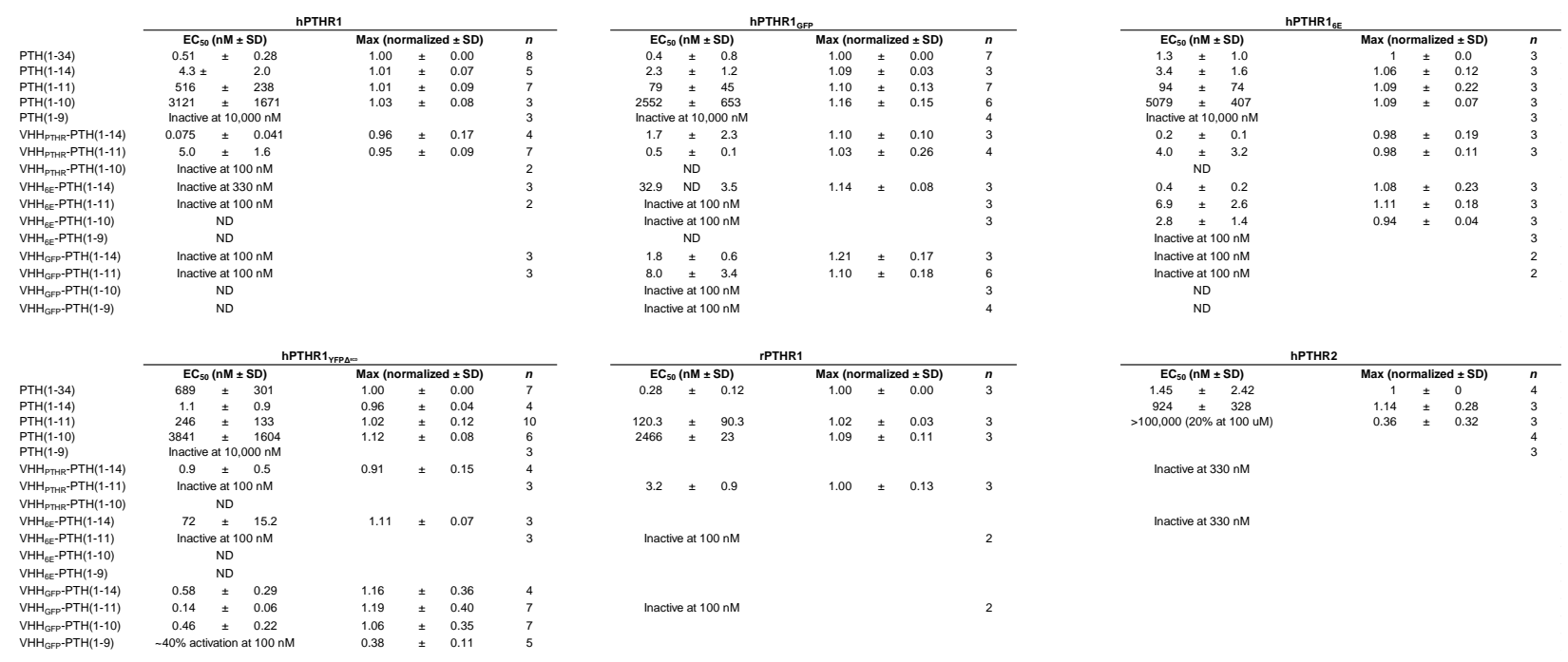

Supporting Table 1. Complete tabulation of cAMP induction assays. Data are identical to those presented in Table 1 and Supporting Figure 12. Maximal responses ("Max") were normalized relative to the top plateau value induced by saturating values of PTH(1-34) for all receptors besides hPTHR1 YFPAECD, for which PTH(1-11) was used. 
